\title{
15. CLAY AND ASSOCIATED MINERALS IN SEDIMENTS FROM THE NAURU BASIN, DEEP SEA DRILLING PROJECT LEG 61 ${ }^{1}$
}

\author{
V. B. Kurnosov, Far-East Geological Institute of the Far-East Science \\ Center of the U.S.S.R. Academy of Sciences, Vladivostok, U.S.S.R. \\ and \\ A. Ya. Shevchenko, Institute of Oceanology, Moscow, U.S.S.R.
}

\section{INTRODUCTION}

Three units of Cenomanian-Pleistocene sediments were drilled at Site 462: from 0 to 297 meters Oligocene-Pleistocene calcareous and radiolarian oozes and chalk, mainly of turibiditic nature; from 297 to $447 \mathrm{me}$ ters Maestrichtian-Eocene chert, chalk, and limestones; from 447 to 599 meters, Cenomanian-Maestrichtian volcaniclastic sandstones, claystones, and limestones. In middle Cretaceous basalts, hyaloclastic sediments are found (Unit IV); in the interval from 560 to 730 meters, they are intercalated with sills. In the other part of the volcanogenic complex, from 730 to 1068 meters, one sedimentary interbed has been found, at a depth of 992 meters.

Sixty samples from sediments of Nauru Basin have been studied mineralogically in the $\langle 2-\mu \mathrm{m}, 2$ to $20-\mu \mathrm{m}$, and $>20-\mu \mathrm{m}$ fractions, and in bulk. Identification of minerals is based on X-ray-diffraction analysis, electron-diffraction analysis, infrared spectral analysis, electron-microscopy data, scanning-electron-microscopy data, wet chemical analysis, and spectral analysis of minor elements. Methods of identification of clay and associated minerals are described in detail in Kurnosov et al. (1980).

\section{MINERALS AND THEIR CHEMICAL COMPOSITION}

Swelling minerals, hydromica, chlorite, kaolinite, mixed-layer chlorite-montmorillonite, palygorskite, sepiolite, clinoptilolite, heulandite-clinoptilolite, cristobalite-tridymite (opal-CT), quartz, feldspar, calcite, analcime-wairakite, actinolite-tremolite, talc, and amorphous phases are identified in sediments from the Nauru Basin.

Dioctahedral and trioctahedral smectite and mixedlayer hydromica-montmorillonite belong to $17 \AA \mathrm{min}$ erals.

Dioctahedral Fe-smectite (Fe-montmorillonite) has a $b$ parameter of 9.04 to $9.09 \AA$ (Table 1). X-ray data and infrared (IR) spectra are normal. A chemical analysis is presented in Table 2. Electron micrographs of Fe-montmorillonite, studied in Samples 462-48-2, 75-77 cm; $462-49-3,1-4 \mathrm{~cm}$; 462-57, CC; 462A-9-3, 58-61 cm; and

\footnotetext{
${ }^{1}$ Initial Reports of the Deep Sea Drilling Project, Volume 61.
}

Table 1. The $b$ parameter of smectites from Leg 61 sediments.

\begin{tabular}{ccc}
\hline $\begin{array}{c}\text { Sample } \\
\text { (interval in cm) }\end{array}$ & $\begin{array}{c}\text { Sub-bottom } \\
\text { Depth } \\
(\mathrm{m})\end{array}$ & $\begin{array}{c}b \text { Parameter } \\
(\AA)\end{array}$ \\
\hline $462-1-2,136-140$ & 3.0 & $9.07,9.21$ \\
$5-2,68-72$ & 40.5 & $9.05,9.25$ \\
$8-4,95-99$ & 72.0 & 9.05 \\
$12-4,8-12$ & 109.5 & $9.02,9.20$ \\
$18-3,74-78$ & 165.5 & 9.05 \\
$36-4,54-57$ & 338.0 & 9.05 \\
$38-1,106-109$ & 353.0 & 9.05 \\
$48-2,75-77$ & 449.0 & 9.06 \\
$49-1,103-106$ & 457.5 & 9.09 \\
$49-3,1-4$ & 459.5 & 9.07 \\
$50-2,138-141$ & 468.5 & $9.07,9.20$ \\
$56-1,147-158$ & 523.5 & 9.09 \\
$57, C C$ & 540.5 & 9.07 \\
$59-1,0-5$ & 549.5 & 9.04 \\
$462 A-9-3,6-11$ & 518.5 & 9.05 \\
$9-3,58-61$ & 519.0 & 9.05 \\
$10-2,109-116$ & 528.0 & 9.04 \\
$11-1,60-68$ & 535.0 & 9.04 \\
$12-1,75-78$ & 544.5 & 9.05 \\
$13-1,110-113$ & 554.5 & 9.05 \\
\hline
\end{tabular}

462-11-1, 60-64 cm usually show a cloud-like shape (Plate 1, Figs. 1, 2, and 3). Besides, they sometimes show plate-like transparent lamellae (Plate 1, Fig. 2), which probably belong to needle-like and plate-like smectites (Kossovskaya and Shutov, 1975; Butuzova et al., 1979). Besides the usual lacy Fe-montmorillonite, which has replaced volcanic glass (Plate 2, Figs. 1 and 2), rounded Fe-montmorillonites of crimp structure (Sample 462-48-2, 75-77 cm; Plate 3, Fig. 1) and columnar ones with a lacy surface (Sample 462-57,CC; Plate 3, Fig. 1) are discovered by the SEM.

Trioctahedral smectite ( $\mathrm{Fe}-\mathrm{Mg}$-saponite) has a $b$ parameter of 9.19 to $9.25 \AA$ (Table 3). According to Mering (1975), saponite belongs to semi-ordered type II. Chemical analyses of saponites with a small impurity of other minerals are presented in Table 4. The saponites contain less $\mathrm{SiO}_{2}$ and more $\mathrm{FeO}$ and $\mathrm{MgO}$ than $\mathrm{Fe}$ montmorillonites.

Electron micrographs of saponites show the usual cloud-like shape, and scanning electron micrographs show a petalous texture (Plate 2, Figs. 3, and 4), as well as plate- and needle-like textures. 
Table 2. Wet chemical analysis of the $<2-\mu \mathrm{m}$ fraction of Leg 61 sediments.

\begin{tabular}{|c|c|c|c|c|c|c|c|c|}
\hline \multirow[b]{2}{*}{ Component } & \multicolumn{8}{|c|}{ Sample } \\
\hline & $\begin{array}{r}462-8-4 \\
95-99 \mathrm{~cm}\end{array}$ & $\begin{array}{l}462-48-2 \text {, } \\
75-77 \mathrm{~cm}\end{array}$ & $\begin{array}{l}462-57-1 \text {, } \\
68-71 \mathrm{~cm}\end{array}$ & $\begin{array}{l}462-60-1 \\
40-42 \mathrm{~cm}\end{array}$ & $\begin{array}{l}462 \mathrm{~A}-9-3 \\
58-61 \mathrm{~cm}^{*}\end{array}$ & $\begin{array}{l}462 \mathrm{~A}-10-2 \\
109-116 \mathrm{~cm}\end{array}$ & $\begin{array}{l}462 \mathrm{~A}-11-1 \\
60-64 \mathrm{~cm}^{*}\end{array}$ & $\begin{array}{l}462 \mathrm{~A}-14-1, \\
85-88 \mathrm{~cm}\end{array}$ \\
\hline $\mathrm{SiO}_{2}$ & 49.20 & 50.30 & 52.60 & 53.10 & 40.60 & 52.60 & 49.80 & 56.90 \\
\hline $\mathrm{TiO}_{2}$ & 1.47 & 2.06 & 1.12 & 0.42 & 1.46 & 0.77 & 1.31 & 0.45 \\
\hline $\mathrm{Al}_{2} \mathrm{O}_{3}$ & 5.43 & 10.21 & 14.58 & 8.05 & 9.94 & 14.85 & 14.59 & 8.09 \\
\hline $\mathrm{Fe}_{2} \mathrm{O}_{3}$ & 21.09 & 8.60 & 8.03 & 13.94 & 9.38 & 9.33 & 11.32 & 8.07 \\
\hline $\mathrm{FeO}$ & 0.41 & 0.41 & 0.41 & 0.48 & 0.34 & 0.27 & 0.34 & 1.03 \\
\hline $\mathrm{MnO}$ & 0.24 & 0.08 & 0.10 & 1.70 & 0.12 & 0.18 & 0.12 & 2.60 \\
\hline $\mathrm{MgO}$ & 9.48 & 5.97 & 3.35 & 2.25 & 4.28 & 3.81 & 3.76 & 3.61 \\
\hline $\mathrm{CaO}$ & 0.00 & 3.05 & 1.60 & 1.21 & 11.97 & 2.41 & 1.12 & 0.96 \\
\hline $\mathrm{Na}_{2} \mathrm{O}$ & 0.40 & 0.68 & 0.38 & 0.22 & 0.38 & 0.32 & 0.57 & 0.24 \\
\hline $\mathrm{K}_{2} \mathrm{O}$ & 0.97 & 0.29 & 1.05 & 2.02 & 1.05 & 2.45 & 1.26 & 1.79 \\
\hline L.o.i. & 7.88 & 10.90 & 9.32 & 10.51 & 15.38 & 8.00 & 10.59 & 8.71 \\
\hline $\mathrm{H}_{2} \mathrm{O}^{-}$ & 3.75 & 7.04 & 7.70 & 6.02 & 5.05 & 5.45 & 5.00 & 7.23 \\
\hline Total & 100.32 & 99.59 & 100.24 & 99.92 & 99.95 & 100.41 & 99.78 & 99.68 \\
\hline
\end{tabular}

- Fe-montmorillonite predominates in the $<2-\mu \mathrm{m}$ fraction.

Table 3. The $b$ parameter of smectites from volcaniclastic sediments in basalt, Leg 61 .

\begin{tabular}{cccc}
\hline $\begin{array}{c}\text { Sample } \\
\text { (interval in cm) }\end{array}$ & $\begin{array}{c}\text { Sub-bottom } \\
\text { Depth } \\
\text { (m) }\end{array}$ & $b(\AA)$ & $\begin{array}{c}\text { Type of } \\
\text { Stacking of } \\
\text { Smectite } \\
\text { Layers* }\end{array}$ \\
\hline $462-64-1,40-42$ & 585.5 & 9.21 & II \\
$64-2,35-38$ & 587.0 & 9.23 & II \\
$64-3,20-24$ & 588.5 & 9.23 & II \\
$65-1,6-8$ & 594.5 & 9.19 & II \\
$462 A-22-2,88-90$ & 590.0 & 9.24 & II \\
$23-1,0-2$ & 597.0 & 9.24 & II \\
$40-1,140-142$ & 703.0 & 9.24 & II \\
$42-2,95-97$ & 722.5 & 9.23 & II \\
$79-6,4-6$ & 992.5 & 9.25 & II \\
$80-1,18-21$ & 994.0 & 9.25 & II \\
$80-1,34-36$ & 994.0 & 9.25 & II \\
$80-2,25-28$ & 995.5 & 9.23 & II \\
$80-2,97-102$ & 996.0 & 9.22 & II \\
\hline
\end{tabular}

* $\mathrm{II}=$ semi-ordered stacking (Mering, 1975)

Mixed-layer, disordered hydromica-montmorillonite is identified in X-ray-diffraction patterns by the asymmetric and broad $17 \AA$ reflection (Dritz and Sakharov, 1976). The ratio of $17 \AA$ peak heights $(Z)$ of the mixed-layer mineral averages 0.5 , whereas that of $\mathrm{Fe}$ montmorillonite is 0.8 to 0.9 (Table 5). The shape of the mixed-layer mineral is the same as that of Fe-montmorillonite, that is, cloud-like (Plate 1, Fig. 5).

Hydromica is dioctahedral, of $1 \mathrm{M}$ and $2 \mathrm{M}$, polytypes. Chlorite is trioctahedral, ferromagnesian, well crystallized, it also may be imperfect, with a hydrated brucite layer. Kaolinite is scarcely identifiable in Sample $462-12-4,8-12 \mathrm{~cm}$ by its IR spectrum. Mixed-layer chlorite-montmorillonite is identified by weak reflections at 11.8 to $12.8 \AA$, after heating at $500^{\circ} \mathrm{C} / \mathrm{hr}$.

Palygorskite-sepiolite are identified in X-ray and electron-diffraction patterns mainly by $10.4-10.5 \AA$ and $11.8 \AA$ reflections and are prominent on electron photomicrographs (Plate 1, Fig. 6; Plate 4, Figs. 1, 2).

Talc is identified in X-ray-diffraction patterns by 9.3 to 9.4 - $\AA$ reflections, but this identification is often indefinite, because the reflection is weak (Table 5).

Clinoptilolite, heulandite-clinoptilolite, cristobalitetridymite, quartz, calcite, analcime-wairakite, actinolite-tremolite, feldspar, and amorphous phases are identified by X-ray (Kurnosov et al., this volume). Plates 5 to 7 show the morphology of secondary minerals.

Chemical composition and minor elements were studied in the $<2-\mu \mathrm{m}$ fraction of sediments from the Nauru Basin. The results are presented in Tables 2, 4, 6, and 7.

\section{DISTRIBUTION OF CLAY AND ASSOCIATED MINERALS IN SEDIMENTS}

\section{Units I and II}

In sediments of Units I and II, pelagic clays include mixed-layer hydromica-montmorillonite, hydromica of $2 \mathrm{M}_{1}$ and $1 \mathrm{M}$ polytypes, chlorite, and admixtures of kaolinite, mixed-layer chlorite-montmorillonite, quartz,

Table 4. Wet chemical analyses of the $<2-\mu \mathrm{m}$ fraction from volcaniclastic sediments interbedded with basalt, Leg 61 .

\begin{tabular}{|c|c|c|c|c|c|c|c|c|}
\hline \multirow[b]{2}{*}{ Component } & \multicolumn{8}{|c|}{ Sample } \\
\hline & $\begin{array}{l}462-63-1 \\
25-27 \mathrm{~cm}\end{array}$ & $\begin{array}{l}462-64-1 \\
40-42 \mathrm{~cm}\end{array}$ & $\begin{array}{l}462-64-2 \\
35-38 \mathrm{~cm}\end{array}$ & $\begin{array}{l}462-64-3 \\
20-24 \mathrm{~cm}\end{array}$ & $\begin{array}{c}462-65-1 \\
6-8 \mathrm{~cm}\end{array}$ & $\begin{array}{c}462 \mathrm{~A}-79-6 \\
4-6 \mathrm{~cm}\end{array}$ & $\begin{array}{c}462 \mathrm{~A}-80-2 \\
25-28 \mathrm{~cm}\end{array}$ & $\begin{array}{l}462 \mathrm{~A}-80-2, \\
97-102 \mathrm{~cm}\end{array}$ \\
\hline $\mathrm{SiO}_{2}$ & 41.52 & 42.25 & 40.75 & 41.45 & 40.65 & 43.10 & 37.20 & 35.95 \\
\hline $\mathrm{TiO}_{2}$ & 0.65 & 0.77 & 0.87 & 0.72 & 0.69 & 1.11 & 1.51 & 1.46 \\
\hline $\mathrm{Al}_{2} \mathrm{O}_{3}$ & 7.66 & 9.85 & 11.74 & 11.40 & 10.78 & 11.80 & 8.48 & 9.02 \\
\hline $\mathrm{Fe}_{2} \mathrm{O}_{3}$ & 11.57 & 10.80 & 11.10 & 9.25 & 10.20 & 11.02 & 13.84 & 13.76 \\
\hline $\mathrm{FeO}$ & 2.67 & 2.74 & 2.39 & 3.83 & 2.97 & 2.67 & 1.78 & 2.05 \\
\hline $\mathrm{MnO}$ & 0.06 & 0.11 & 0.11 & 0.14 & 0.14 & 0.17 & 0.10 & 0.12 \\
\hline $\mathrm{MgO}$ & 10.33 & 12.83 & 10.52 & 12.25 & 11.10 & 8.21 & 11.79 & 11.68 \\
\hline $\mathrm{CaO}$ & 2.32 & 1.45 & 2.09 & 1.61 & 1.61 & 3.54 & 2.57 & 2.09 \\
\hline $\mathrm{Na}_{2} \mathrm{O}$ & 0.65 & 0.27 & 0.24 & 0.14 & 0.24 & 3.08 & 0.24 & 0.37 \\
\hline $\mathrm{K}_{2} \mathrm{O}$ & 0.29 & 0.96 & 1.70 & 1.73 & 1.64 & 0.52 & 0.11 & 0.16 \\
\hline L.o.i. & 14.14 & 10.93 & 11.12 & 10.28 & 11.64 & 8.68 & 15.03 & 15.24 \\
\hline $\mathrm{H}_{2} \mathrm{O}^{-}$ & 8.25 & 7.19 & 6.91 & 7.00 & 7.89 & 5.71 & 7.16 & 7.81 \\
\hline Total & 100.11 & 100.15 & 99.54 & 99.80 & 99.55 & 99.61 & 99.81 & 99.71 \\
\hline
\end{tabular}


feldspar, and clinoptilolite (Table 5). The composition of this complex of minerals, excluding clinoptilolite, is invariable through the whole Oligocene-Pleistocene section. It is impoverished in calcite and amorphous phases to various degrees. When calcite and (or) amorphous phases prevail in carbonaceous and siliceous sediments, clay minerals often occur as an admixture. We failed to separate the $<2-\mu \mathrm{m}$ fraction from carbonaceous sediments.

Sample 462-8-4, 95-99 cm contradicts the regularity of mineral distribution in Units I and II. The $<2-\mu \mathrm{m}$ fraction from this sample consists of $\mathrm{Fe}$-montmorillonite, with hydromica, palygorskite, clinoptilolite, and cristobalite-tridymite admixtures. Fragments of alkali and tholeiitic basalts were separated from the $>20-\mu \mathrm{m}$ fraction. Altered fragments of tholeiitic basalt are composed of $\mathrm{Fe}-\mathrm{Mg}$-saponite. Fragments of alkali glass are fresh. Fresh fragments of alkali glass also occur in Sample 462-15-1, 44-47 cm.

\section{Unit III}

The mineral complex of volcaniclastic sediments of Unit III differs in composition from those of Units I and II. The main differences are as follows. In sediments of Unit III Fe-montmorillonite prevails among clay minerals; kaolinite and trioctahedral minerals (chlorite and mixed-layer chlorite-montmorillonite) are practically lacking. Some layers are rich in palygorskite. Volcaniclastic sediments contain much clinoptilolite. In the lower part of the unit, at the contact with basalt, there is a large amount of siliceous minerals: quartz and cristobalite-tridymite (Table 5).

In these sediments, red and pinkish clays (Samples 462-56-1, 147-158 cm; 462-59-1, 0-5 cm; 462A-10-2, $109-116 \mathrm{~cm}$; 462A-12-1, 75-78 cm; 462A-13-1, 110-113 $\mathrm{cm})$ are polymineralic and comprise much palygorskite, as well as mixed-layer hydromica-montmorillonite and $2 \mathrm{M}_{1}$ and $1 \mathrm{M}$ hydromica. Sometimes red clays contain chlorite and kaolinite admixtures. Dark-brown clays and argillites (Samples 462-57-1, 68-71 cm; 462-58-4, 6-10 cm; 462A-11-1, 60-64 cm) interbanded with red clays either do not contain palygorskite or contain very little. In the $<2-\mu \mathrm{m}$ fraction, Fe-montmorillonite prevails (Table 5). In the $2-$ to $20-\mu \mathrm{m}$ and $>20-\mu \mathrm{m}$ fractions, mixed-layer hydromica-montmorillonite contains less hydromica packets than the mixed-layer mineral from red clays.

The mineralogical composition of volcaniclastic sandstones (Hole 462, Cores 48-51, 57; 462A-7-1, 46-51 cm) and argillite at the contact with basalt (Sample 462A$14-1,85-88 \mathrm{~cm}$ ) is like that of the dark-brown clays. Femontmorillonite is a primary clay mineral in sandstone. The 2- to $20-\mu \mathrm{m}$ and $>20-\mu \mathrm{m}$ fractions comprise mixedlayer hydromica-montmorillonite, hydromica, and chlorite, with kaolinite.

Clinoptilolite occurs in sediments of all types, although it is most common in clays and argillites and is concentrated in the 2 - to $20-\mu \mathrm{m}$ and $>20-\mu \mathrm{m}$ fractions (Table 5). In the lower part of Unit III clinoptilolite is lacking in sediments at the contact with basalt. Feldspar is observed in almost all samples. The largest quantity of quartz is found in sediments about 10-meters thick near the contact. Above this, quartz is replaced by cristobalite-tridymite. Calcite is found in large quantities in the uppermost sediments of Unit III, down to 519 meters. Small quantities of sepiolite are identified by electron-diffraction analysis in Samples 462-49-1, 103$106 \mathrm{~cm}$; 462-50-2, 138-141 cm. Sepiolite occurs with palygorskite.

Two fragments of sandstones of the upper part of Unit III (Sample 462-48-2, 75-77 cm) were analyzed. A fragment of white siliceous rock is composed of calcite, cristobalite-tridymite, clinoptilolite, and admixtures of quartz and 17- $\AA$ mineral. A green fragment of altered volcanic glass consists mainly of Fe-montmorillonite, feldspar, and amorphous phases, with a broad reflection near $4.45 \AA$, typical of palagonite.

\section{Unit IV}

Twenty-four samples from volcaniclastic interbeds of the Nauru Basin sill complex were analyzed. The mineralogy of these samples was studied in bulk. Other samples were studied in $\langle 2-\mu \mathrm{m}, 2-$ to $20-\mu \mathrm{m}$, and $>20-\mu \mathrm{m}$ fractions (Table 8). The mineralogical composition of volcaniclastic sediments from the sill complex is peculiar and differs sharply from sediments overlying basalts, including volcaniclastic sediments of Unit III (Table 8).

In all samples analyzed in bulk and in fractions, $\mathrm{Fe}-$ $\mathrm{Mg}$-saponite is the principal mineral. Other minerals (hydromica, chlorite, analcime-wairakite, heulanditeclinoptilolite, actinolite-tremolite, and talc) occur as admixtures. Among admixture minerals, analcime-wairakite is most common, chlorite and actinolite-tremolite are also widespread. Heulandite-clinoptilolite is identified in that part of the section in which the participants of Leg 61 found zeolite veinlets in sediments. Talc is found in the lowermost sedimentary interbeds between thick sills (Table 8).

The chemical composition of volcaniclastic sediments overlying basalt and within basalts is compared in the $<2-\mu \mathrm{m}$ fraction (Tables 2 and 4 ); the results are presented in a triangular diagram for the $<2-\mu \mathrm{m}$ fraction composition, involving $\mathrm{Fe}_{2} \mathrm{O}_{3}+\mathrm{FeO}, \mathrm{Al}_{2} \mathrm{O}_{3}$, and $\mathrm{MgO}$ (Fig. 1), and in a rectangular diagram of $\left(\mathrm{Fe}_{2} \mathrm{O}_{3}+\mathrm{FeO}\right.$ $+\mathrm{MgO}) / \mathrm{Al}_{2} \mathrm{O}_{3}$ and $\mathrm{Na}_{2} \mathrm{O}+\mathrm{K}_{2} \mathrm{O}$ (Fig. 2). The diagrams show that sediments interbedded with basalt contain more magnesium and less $\mathrm{Al}_{2} \mathrm{O}_{3}$ than sediments overlying the sill complex. Two samples (462-8-4, 95-99 $\mathrm{cm}$, from a volcaniclastic interbed in terrigenous sediment of Unit I; 462-60-1, 40-42 cm, from a near-contact layer) are exceptions. They are enriched in $\mathrm{Fe}_{2} \mathrm{O}_{3}$ (Table 2).

The total alkalies in volcaniclastic sediments of Units III and IV are identical (Fig. 2). Only in the lowermost sedimentary interbed in basalt, at a depth of 992 meters, is the alkali content in Core 80 decreased, and in Core 79 is the lowest $\mathrm{Na}_{2} \mathrm{O}$ content, $3.08 \%$ (Table 4).

Sediments overlying basalts contain more $\mathrm{SiO}_{2}$ than sediments within basalts (Tables 2 and 4).

In sediments overlying basalt, with the approach to the contact $\mathrm{SiO}_{2}, \mathrm{MnO}, \mathrm{K}_{2} \mathrm{O}, \mathrm{Fe}_{2} \mathrm{O}_{3}+\mathrm{FeO}$ (Hole 462), and $\mathrm{FeO}\left(\mathrm{Hole} 462 \mathrm{~A}\right.$ ) increase, whereas $\mathrm{TiO}_{2}, \mathrm{Al}_{2} \mathrm{O}_{3}$, 
Table 5. Clay-mineral compositions and fractions of related minerals (\%): $<2 \mu \mathrm{m}(1), 2-20 \mu \mathrm{m}(2)$, and $>20 \mu \mathrm{m}(3)$, Site 462 .

\begin{tabular}{|c|c|c|c|c|c|c|c|c|c|c|c|c|c|c|c|}
\hline \multirow{2}{*}{$\begin{array}{c}\text { Sample } \\
\text { (interval in } \mathrm{cm} \text { ) }\end{array}$} & \multirow{2}{*}{$\begin{array}{l}\text { Sub-bottom } \\
\text { Depth } \\
\text { (m) }\end{array}$} & \multirow[b]{2}{*}{ Lithology } & \multirow[b]{2}{*}{ Age } & \multicolumn{3}{|c|}{$\begin{array}{c}17-\AA \\
\text { Minerals }\end{array}$} & \multicolumn{3}{|c|}{ Hydromica } & \multicolumn{3}{|c|}{$\underset{\text { Kaolinite }}{\text { Chlorite + }}$} & \multicolumn{3}{|c|}{$\begin{array}{c}\text { Mixed- } \\
\text { Layer } \\
\text { Chlorite- } \\
\text { Montmorillonite }\end{array}$} \\
\hline & & & & 1 & 2 & 3 & 1 & 2 & 3 & 1 & 2 & 3 & 1 & 2 & 3 \\
\hline $462-1-1,22-26$ & 0.5 & Unit 1 : calcareous & Pleistocene & & 30 & & & 50 & & & 20 & & & & \\
\hline $1-2,136-140$ & 3.0 & and radiolarian oozes & & 47 & 45 & & 32 & 30 & & 21 & 25 & & $\operatorname{tr}$ & $\operatorname{tr}$ & \\
\hline $3-5,16-19$ & 25.5 & and chalks & & 75 & & & 15 & & & 10 & & & $\mathrm{tr}$ & & \\
\hline $4-4,48-50$ & 33.5 & & & & 75 & $\operatorname{tr}$ & & 15 & & & 10 & & & & \\
\hline $4-5,116-128$ & 36.0 & & & & 70 & & & 15 & & & 15 & & & $\operatorname{tr}$ & \\
\hline $5-2,68-72$ & 40.5 & & & 75 & 65 & & 15 & 20 & & 10 & 15 & & $\operatorname{tr}$ & $\operatorname{tr}$ & \\
\hline $6-4,91-95$ & 53.0 & & & 78 & 80 & $\operatorname{tr}$ & 11 & 15 & & 11 & 5 & & $\operatorname{tr}$ & $\operatorname{tr}$ & \\
\hline $8-4,95-99$ & 72.0 & & & 100 & 85 & $\operatorname{tr}$ & tr & 10 & $\operatorname{tr}$ & & 5 & & & $\operatorname{tr}$ & \\
\hline $10-3,62-65$ & 89.5 & & Middle & 60 & 70 & $\operatorname{tr}$ & 30 & 20 & tr & 10 & 10 & $\mathrm{tr}$ & & $\operatorname{tr}$ & \\
\hline $11-3,138-142$ & 99.5 & & Miocene & 65 & 65 & & 18 & 20 & & 17 & 15 & & $\operatorname{tr}$ & $\operatorname{tr}$ & \\
\hline $12-4,8-12$ & 109.5 & & & 70 & 60 & & 20 & 30 & & 10 & 10 & & $\operatorname{tr}$ & $\operatorname{tr}$ & \\
\hline $13-1,58-62$ & 115.0 & & & & tr & & & & & & & & & & \\
\hline $14-6,65-67$ & 132.0 & & Early & 60 & 60 & $\operatorname{tr}$ & 25 & 20 & $\operatorname{tr}$ & 15 & 20 & $\mathrm{tr}$ & $\operatorname{tr}$ & $\mathrm{tr}$ & \\
\hline $15-1,44-47$ & 143.0 & & Miocene & & 60 & $\mathrm{tr}$ & & 20 & tr & & 20 & tr & & $\mathrm{tr}$ & \\
\hline $17-2,109-113$ & 155.0 & & Late & & 90 & & & 10 & & & $\mathrm{tr}$ & & & $\operatorname{tr}$ & \\
\hline $18-3,74-78$ & 165.5 & & Oligocene & 90 & 90 & & 7 & 5 & & 3 & 5 & & & $\operatorname{tr}$ & \\
\hline $19-4,114-118$ & 176.5 & & & 70 & 75 & 75 & 25 & 15 & 10 & 5 & 10 & 15 & $\operatorname{tr}$ & $\operatorname{tr}$ & \\
\hline $20-4,83-87$ & 186.0 & & & & 90 & & & 10 & & & & & & & \\
\hline $24-4,65-68$ & 224.0 & & & tr & 100 & & $\mathrm{tr}$ & & & $\mathrm{tr}$ & & & & & \\
\hline $25-3,92-95$ & 232.0 & & & & tr & & & & & & & & & & \\
\hline $27-3,84-87$ & 251.0 & & Early & & tr & & & & & & & & & & \\
\hline $28-6,102-108$ & 265.5 & & Oligocene & & tr & & & & & & & & & & \\
\hline $36-4,54-57$ & 338.0 & Unit 2: cherts, chalks, & Eocene & 75 & 75 & $\operatorname{tr}$ & 15 & 15 & & 10 & 10 & & $\operatorname{tr}$ & tr & \\
\hline $38-1,106-109$ & 353.0 & and limestones & & 80 & 65 & & 15 & 20 & & 5 & 15 & & $\operatorname{tr}$ & $\mathrm{tr}$ & \\
\hline $39-2,100-104$ & 364.0 & & & 75 & 75 & & 20 & 20 & & 5 & 5 & & & & \\
\hline $462 \mathrm{~A}-7-1,46-51$ & 439.5 & & Maestrichtian & 100 & 100 & $\operatorname{tr}$ & & & & & & & & & \\
\hline $48-2,75-77$ & 449.0 & Unit 3: volcaniclastic & & 100 & 100 & 100 & & & & & & & & & \\
\hline $462-49-1,103-106$ & 457.5 & sediments, zeolitic & & 100 & & & & & & & & & & & \\
\hline $49-3,1-4$ & 459.5 & claystones, and & & 95 & 85 & & 5 & 10 & & & 5 & & & & \\
\hline $50-2,138-141$ & 468.5 & black shales & & 85 & 90 & 100 & 10 & 5 & & 5 & 5 & & & & \\
\hline $51-2,55-63$ & 477.5 & & & & & 95 & & & 5 & & & & & & \\
\hline $462 \mathrm{~A}-9-3,6-11$ & 518.5 & & Early & 70 & & & 30 & & & & & & & & \\
\hline $9-3,58-61$ & 519.0 & & Campanian & 100 & 100 & 100 & $\operatorname{tr}$ & tr & & & & & & & \\
\hline $462-56-1,147-158$ & 523.5 & & $?$ & 50 & 35 & & 30 & 52 & & 2 & 3 & & & & \\
\hline $462 \mathrm{~A}-10-2,109-116$ & 528.0 & & & 60 & 40 & 40 & 18 & 40 & 35 & 2 & 5 & 2 & & & \\
\hline $462-57-1,68-71$ & 532.0 & & Early & 100 & 100 & & $\operatorname{tr}$ & & & & & & & & \\
\hline $462 \mathrm{~A}-11-1,60-64$ & 535.0 & & Santonian & 100 & 100 & 90 & $\operatorname{tr}$ & & 10 & & & & & & \\
\hline $462-57, \mathrm{CC}$ & 540.5 & & & 100 & 100 & 100 & & & & & & & & & \\
\hline $58-2,32-35$ & 542.0 & & Early & tr & & & tr & & & & & & & & \\
\hline $462 \mathrm{~A}-12-1,75-78$ & 544.5 & & Santonian- & & 55 & & & 25 & & & & & & & \\
\hline $462-58-4,6-10$ & 545.0 & & Late Turonian & 100 & 95 & 90 & & 5 & 10 & & & & & & \\
\hline $59-1,0-5$ & 549.5 & & Cenomanian & $\mathrm{tr}$ & $\operatorname{tr}$ & 90 & tr & $\operatorname{tr}$ & $\operatorname{tr}$ & & & & & & \\
\hline $462 A-13-1,110-113$ & 554.5 & & & $\operatorname{tr}$ & tr & 40 & 85 & 85 & 40 & & & & & & \\
\hline $462-60-1,40-42$ & 558.5 & & & 80 & 80 & 90 & 20 & 20 & 10 & & & & & & \\
\hline $462 \mathrm{~A}-14-1,85-88$ & 563.5 & & & 100 & 75 & 75 & & 20 & 20 & & 5 & 5 & & & \\
\hline
\end{tabular}

$++=$ abundant,$+=$ common, $\mathrm{tr}=$ trace .

$\mathrm{Fe}_{2} \mathrm{O}_{3}$ (Hole 462A), $\mathrm{MgO}, \mathrm{CaO}$, and $\mathrm{Na}_{2} \mathrm{O}$ decrease (Table 2). $\mathrm{Cr}, \mathrm{Ni}, \mathrm{Co}, \mathrm{Sc}, \mathrm{Pb}$, and especially $\mathrm{Cu}$ contents increase in sediments with the approach to the contact with basalts. This peculiarity in minor-element distribution is prominent in Hole $462 \mathrm{~A}$ and is lacking in Hole 462 (Table 6).

\section{GENESIS OF MINERALS}

\section{Units I and II}

In Eocene-Pleistocene time, calcareous and siliceous sediments accumulated in Nauru Basin; clay minerals were primarily terrigenous. A complex of clay minerals typical of terrigenous sediments of the Pacific equatorial sector on the whole is found in interbeds of pelagic clays (Griffin et al., 1968). This complex consists of mixed-layer hydromica-montmorillonite, $2 \mathrm{M}_{1}$ and $1 \mathrm{M}$ hydromica, chlorite, and an admixture of kaolinite and mixed-layer chlorite-montmorillonite, quartz, feldspar, and amorphous phases.

The background accumulation of pelagic clays was restrained to various degrees by active calcareous accumulation. Sediments with calcite were introduced by suspension flows from the slopes of the Marshall Islands and Caroline Islands, surrounding Nauru Basin (data of participants of Leg 61). The composition of the clay-mineral complex in the calcareous and carbonaceous sediments is the same as in the pelagic clays.

Thus, from the Eocene to the Recent, homogeneous clay material was introduced into Nauru Basin. Streams which transported it were stable in that period. Accumulation of silica prevailed in the Eocene and continued 
Table 5. (Continued).

\begin{tabular}{|c|c|c|c|c|c|c|c|c|c|c|c|c|c|c|c|c|c|c|c|c|c|c|c|}
\hline \multirow[b]{2}{*}{1} & \multicolumn{2}{|l|}{$Z$} & \multicolumn{3}{|c|}{$\begin{array}{l}\text { Palygorskite- } \\
\text { Sepiolite }\end{array}$} & \multicolumn{3}{|c|}{ Quartz } & \multicolumn{3}{|c|}{ Feldspar } & \multicolumn{3}{|c|}{ Clinoptilolite } & \multicolumn{3}{|c|}{$\begin{array}{l}\text { Cristobalite- } \\
\text { Tridymite }\end{array}$} & \multicolumn{3}{|c|}{ Calcite } & \multicolumn{3}{|c|}{ Amorphous Phases } \\
\hline & 2 & 3 & 1 & 2 & 3 & 1 & 2 & 3 & 1 & 2 & 3 & 1 & 2 & 3 & 1 & 2 & 3 & 1 & 2 & 3 & 1 & 2 & 3 \\
\hline & 0.5 & & & & & & + & & & $\mathrm{tr}$ & & & & & & & & & & & & $\mathrm{tr}$ & \\
\hline 0.6 & 0.4 & & & & & + & + & & $\mathrm{tr}$ & + & & & & & & & & & & & tr & $\mathrm{tr}$ & \\
\hline 0.7 & & & & & & tr & & & $\mathrm{tr}$ & & & & & & & & & & & & $\mathrm{tr}$ & & \\
\hline & 0.5 & 0.5 & & & & & tr & $\mathrm{tr}$ & & $\mathrm{tr}$ & $\mathrm{tr}$ & & & & & & & & ++ & + & tr & $\mathrm{tr}$ & \\
\hline & 0.6 & & & & & & tr & & & tr & & & & & & & & & & & + & + & \\
\hline 0.6 & 0.4 & & & & & $\mathrm{tr}$ & tr & & $\mathrm{tr}$ & tr & & & & & & & & & & & + & + & \\
\hline 0.4 & 0.6 & 0.5 & & & & $\mathrm{tr}$ & $\mathrm{tr}$ & & tr & tr & & & & & & & & & & & + & + & + \\
\hline 0.8 & 0.6 & & $\mathrm{tr}$ & & & & tr & $\mathrm{tr}$ & $\mathrm{tr}$ & $\mathrm{tr}$ & $\mathrm{tr}$ & $\mathrm{tr}$ & & & $\mathrm{tr}$ & & & & ++ & tr & & $\mathrm{tr}$ & ++ \\
\hline 0.3 & 0.3 & 0.3 & & & & tr & $\mathrm{tr}$ & $\mathrm{tr}$ & $\mathrm{tr}$ & 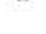 & & & $\mathrm{tr}$ & & & & & & & $\mathrm{tr}$ & + & + & ++ \\
\hline 0.5 & 0.4 & & & & & $\mathrm{tr}$ & tr & & $\mathrm{tr}$ & tr & & & $\mathrm{tr}$ & & & & & & & & + & + & \\
\hline 0.5 & 0.5 & & & & & tr & tr & & $\operatorname{tr}$ & $\operatorname{tr}$ & & & & & & & & & & & + & + & \\
\hline 0.4 & 0.4 & 0.4 & & & & $\mathrm{tr}$ & tr & tr & $\mathrm{tr}$ & tr & tr & & & & & & & & ++ & ++ & + & + & + \\
\hline & 0.5 & 0.5 & & & & & & $\mathrm{tr}$ & & & $\mathrm{tr}$ & & & & & & & & ++ & ++ & + & & $\mathrm{tr}$ \\
\hline & 0.5 & & & & & & tr & & & $\mathrm{tr}$ & & & & & & & & & tr & & & + & \\
\hline 0.6 & 0.5 & & & & & $\mathrm{tr}$ & $\mathrm{tr}$ & & $\mathrm{tr}$ & $\mathrm{tr}$ & & tr & tr & & & & & & & & tr & + & \\
\hline 0.3 & 0.6 & 0.3 & & & & $\mathrm{tr}$ & $\mathrm{tr}$ & $\operatorname{tr}$ & tr & $\operatorname{tr}$ & $\mathrm{tr}$ & $\mathrm{tr}$ & & & & & & & & & + & + & + \\
\hline & 0.6 & & & & & & & & & $\mathrm{tr}$ & & & $\mathrm{tr}$ & & & & & & + & & & $\mathrm{tr}$ & \\
\hline & 0.5 & & & & & tr & & & $\mathrm{tr}$ & & & + & & & tr & & & & $\begin{array}{l}++ \\
++\end{array}$ & & + & $\begin{array}{l}+ \\
t r\end{array}$ & \\
\hline & & & & & & & & & & & & & & & & & & & $\begin{array}{l}++ \\
++\end{array}$ & + & & & + \\
\hline 0.4 & 0.5 & 0.3 & & & & $\mathrm{tr}$ & $\mathrm{tr}$ & $\operatorname{tr}$ & $\operatorname{tr}$ & $\operatorname{tr}$ & & & & & & & & & & & + & + & ++ \\
\hline 0.4 & 0.3 & & tr & & & $\mathrm{tr}$ & $\mathrm{tr}$ & & tr & $\mathrm{tr}$ & & & & & & & & & & & + & + & \\
\hline & 0.4 & & & & & $\mathrm{tr}$ & & & $\mathrm{tr}$ & & & & & & & & & & & & ++ & ++ & \\
\hline 0.9 & 0.8 & & & & & & & & & & & tr & + & + & & & & $\mathrm{tr}$ & ++ & ++ & & & \\
\hline 0.9 & 0.9 & 0.7 & & & & & & & & tr & & & & & & & & & tr & + & & tr & $\operatorname{tr}$ \\
\hline 0.6 & & & $\mathrm{tr}$ & & & & & & & & & $\mathrm{tr}$ & & & $\mathrm{tr}$ & & & ++ & & & tr & & \\
\hline 0.8 & 0.7 & & & & & & & & & & & $\mathrm{tr}$ & ++ & & & & & & & & & & \\
\hline 0.8 & 0.8 & 0.8 & $\operatorname{tr}$ & & & & & & $\operatorname{tr}$ & tr & & & & & & & & & tr & & & $\operatorname{tr}$ & $\operatorname{tr}$ \\
\hline & & 0.7 & & & & & & & & & & & & tr & & & & & & ++ & & & tr \\
\hline 0.8 & & & $\mathrm{tr}$ & & & $\mathrm{tr}$ & & & $\mathrm{tr}$ & & & $\mathrm{tr}$ & & & & & & ++ & & & tr & & \\
\hline 0.9 & 0.9 & 0.8 & $\mathrm{tr}$ & & & & & & & $\operatorname{tr}$ & & & & + & & & & + & tr & + & & & \\
\hline 0.6 & 0.4 & & 18 & 10 & & tr & + & & tr & + & & & + & & & & & & & & $\mathrm{tr}$ & tr & \\
\hline 0.7 & 0.4 & 0.4 & 20 & 15 & 23 & tr & + & $\operatorname{tr}$ & $\mathrm{tr}$ & + & $\mathrm{tr}$ & $\mathrm{tr}$ & tr & tr & & & & & & & & tr & tr \\
\hline 0.9 & 0.8 & & & & & & & & $\mathrm{tr}$ & $\mathrm{tr}$ & & $\mathrm{tr}$ & $\mathrm{tr}$ & & & & & & & & & & \\
\hline 0.8 & 0.6 & 0.6 & $\mathrm{tr}$ & & & & tr & $\mathrm{tr}$ & tr & + & tr & $\mathrm{tr}$ & ++ & ++ & & & & & & $\mathrm{tr}$ & & tr & $\mathrm{tr}$ \\
\hline 0.9 & 0.8 & 0.6 & & & & & & & $\operatorname{tr}$ & + & $\mathrm{tr}$ & & $\operatorname{tr}$ & tr & & & & & & $\operatorname{tr}$ & & tr & $\operatorname{tr}$ \\
\hline & 0.4 & & & 15 & & tr & & & & & & & & & ++ & & & & & & & & \\
\hline 0.8 & 0.6 & 0.6 & & 15 & & & tr & tr & & $\begin{array}{l}\mathrm{tr} \\
\mathrm{tr}\end{array}$ & $\mathrm{tr}$ & & $\begin{array}{c}++ \\
+\end{array}$ & ++ & $\mathrm{tr}$ & $\begin{array}{l}\text { tr } \\
\text { tr }\end{array}$ & $\operatorname{tr}$ & & & & & $\begin{array}{l}\text { tr } \\
\text { tr }\end{array}$ & tr \\
\hline & & 0.4 & $\operatorname{tr}$ & $\operatorname{tr}$ & 10 & + & + & + & & 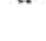 & $\mathrm{tr}$ & $\mathrm{tr}$ & + & $\mathrm{tr}$ & ++ & + & + & & & $\mathrm{tr}$ & tr & $\mathrm{tr}$ & $\mathrm{tr}$ \\
\hline & & 0.4 & 15 & 15 & 20 & ++ & ++ & ++ & $\mathrm{tr}$ & $\mathrm{tr}$ & tr & + & ++ & + & & & $\mathrm{tr}$ & & & & $\mathrm{tr}$ & tr & $\mathrm{tr}$ \\
\hline 0.2 & 0.4 & 0.6 & & & & + & + & ++ & & & & & & & & & & & & 、 & & & \\
\hline 0.9 & 0.6 & 0.7 & & & & & ++ & ++ & & & & & & & & & & & & & & & \\
\hline
\end{tabular}

Table 6. Trace elements (ppm) in the $<2-\mu \mathrm{m}$ fraction of Leg 61 sediments.

\begin{tabular}{lcrrrrrrrrr}
\hline $\begin{array}{c}\text { Sample } \\
\text { (interval in cm) }\end{array}$ & $\begin{array}{c}\text { Sub-bottom } \\
\text { Depth } \\
\text { (m) }\end{array}$ & $\mathrm{Cr}$ & $\mathrm{Ni}$ & $\mathrm{V}$ & $\mathrm{Co}$ & $\mathrm{Zr}$ & $\mathrm{Sc}$ & $\mathrm{Pb}$ & $\mathrm{Sn}$ & $\mathrm{Cu}$ \\
\hline $462-8-4,95-99$ & 72.0 & 100 & 175 & 30 & 40 & 160 & 21 & 5 & - & 160 \\
$48-2,75-77$ & 449.0 & 30 & 61 & 112 & - & 89 & 7 & - & - & 34 \\
$50-2,138-141$ & 468.5 & 80 & 220 & 65 & 37 & 115 & 15 & 9 & - & 25 \\
$57-1,68-71$ & 532.0 & 40 & 91 & 180 & 14 & 148 & 25 & 6 & - & 83 \\
$59-1,0-5$ & 549.5 & 45 & 70 & 45 & 12 & 150 & 12 & 9 & - & 200 \\
$60-1,40-42$ & 558.5 & 28 & 60 & 83 & 25 & 79 & 19 & 9 & 7 & 300 \\
$462 \mathrm{~A}-9-3,58-61$ & 518.5 & 39 & 120 & 120 & 25 & 160 & 13 & 11 & - & 16 \\
$10-2,109-116$ & 528.0 & 30 & 75 & 64 & 25 & 107 & 17 & 14 & - & 57 \\
$11-1,60-64$ & 535.0 & 30 & 120 & 120 & 35 & 160 & 19 & 14 & - & 57 \\
$13-1,110-113$ & 554.5 & 43 & 160 & 66 & 63 & 150 & 25 & 19 & - & 200 \\
$14-1,85-89$ & 563.5 & 40 & 105 & 140 & 180 & 120 & 27 & 17 & 3 & 220 \\
\hline
\end{tabular}

to the late Pleistocene. In the Oligocene-Pleistocene, silica accumulation was accompanied by intensive introduction of carbonates, which often prevailed.

In some layers of Unit I containing volcaniclastic material (Sample 462-8-4, 95-99 cm), Fe-montmorillonite as well as an admixture of palygorskite, clinoptilolite, and cristobalite-tridymite were formed, mainly because of decomposition of volcanic glass. The fragments of tholeiitic basalts with trioctahedral smectite (Fe-Mg-saponite) in the coarse fraction of the volcaniclastic material show that the basalt complex studied in Holes 462 and $462 \mathrm{~A}$ has undergone erosion. Fragments 
Table 7. Trace elements (ppm) in the $<2-\mu \mathrm{m}$ fraction of sediments interbedded with basalt, Leg 61 .

\begin{tabular}{ccccccccccc}
\hline $\begin{array}{c}\text { Sample } \\
\text { (interval in cm) }\end{array}$ & $\begin{array}{c}\text { Sub-bottom } \\
\text { Depth } \\
(\mathrm{m})\end{array}$ & $\mathrm{Cr}$ & $\mathrm{Ni}$ & $\mathrm{V}$ & $\mathrm{Co}$ & $\mathrm{Zr}$ & $\mathrm{Sc}$ & $\mathrm{Pb}$ & $\mathrm{Sn}$ & $\mathrm{Cu}$ \\
\hline $462-64-2,35-38$ & 587.0 & 112 & 87 & 170 & 34 & 65 & 44 & - & - & 80 \\
$64-3,20-24$ & 588.5 & 110 & 90 & 150 & 30 & 63 & 50 & - & - & 73 \\
$462 \mathrm{~A}-79-6,4-6$ & 992.5 & 60 & 66 & 190 & 25 & 63 & 48 & 5 & - & 118 \\
$80-2,25-28$ & 995.5 & 125 & 120 & 112 & - & 57 & 38 & - & - & 75 \\
$80-2,97-102$ & 996.0 & 120 & 140 & 180 & - & 65 & 40 & - & - & 46 \\
\hline
\end{tabular}

of slightly altered alkali volcanic glass in Samples $462-8-4,95-99 \mathrm{~cm}$ and $462-15-1,44-47 \mathrm{~cm}$ reflect the activation of island alkali volcanism (Shcheka, this volume).

Diagenetic changes of clay minerals in sediments of Units I and II have not been observed.

\section{Unit III}

In Cenomanian-Maestrichtian time, abundant volcaniclastic material was introduced into the Nauru Basin, which determined the mineralogical composition of sediments of Unit III. Alteration of volcanic glass in sandstones and clays caused the formation of Fe-montmorillonite, clinoptilolite, and probably some $1 \mathrm{M}$ mica. Residues of palagonitized glass are visible in thin sections of sandstones; they are also visible in X-ray-diffraction patterns by the amorphous background and broad, asymmetric $4.5-\AA$ reflection. This reflection is common in X-ray-diffraction patterns of palagonitized glass in samples from the Pacific and Indian Oceans.

Mixed-layer hydromica-montmorillonite, which represents $17-\AA$ minerals in red clays and in the 2- to $20-\mu \mathrm{m}$ and $>20-\mu \mathrm{m}$ fractions of brown clays, is probably terrigenous. $2 \mathrm{M}_{1}$, and particularly $1 \mathrm{M}$ hydromica, as well as chlorite, kaolinite, calcite, amorphous phases, feld- spar, and quartz, also are terrigenous. This complex of terrigenous minerals is typical of oceanic sediments (Griffin et al., 1968; Gorbunova, 1970).

The formation of the upper sediments of Unit III, down to 519 meters, was accompanied by intensive calcite introduction, suggesting the existence of reefs around the Nauru Basin from the early Campanian to the Pleistocene, inclusive.

The history of palygorskite formation is obscure. There may have been several ways of its formation in sediments of Nauru Basin. Hydrothermal palygorskite growth is due to supply of magnesium solutions from a sill complex (Bonatti and Joensuu, 1968, 1969; Gorbunova, 1972; Lomova, 1975a, 1975b, 1979; Skornyakova et al., 1978), although the uneven and broken distribution of palygorskite in sediments of Unit III contradicts this (Table 5). The source of terrigenous palygorskite in Nauru Basin is obscure; also scanning electron micrographs do not show a terrigenous character.

Some students suggest authigenic palygorskite formation (Peterson et al., 1970; Zemmels and Cook, 1974; Couture, 1977). The occurrence of palygorskite mainly in red clays allows us to consider that the physical- chemical regime of red-clay formation is more favorable for the formation of palygorskite than for brown clays. At the same time, a high palygorskite content is found in Cretaceous brown clays in the northwestern Pacific Ocean (Leg 20; Matti et al., 1973). Thus, a conclusion about preferential conditions for the formation of palygorskite is unfounded. The assumption that during accumulation of red clays the material which easily released $\mathrm{Mg}$ was introduced to Nauru Basin is most probable. Such material was probably trioctahedral smectite, which could alter to dioctahedral smectite under oxidizing conditions. In this case, $\mathrm{Fe}^{+2}$ ox-

Table 8. Summary of identified minerals in volcaniclastic sediments from interbeds in basalts, Leg $61:<2 \mu \mathrm{m}(1), 2-20 \mu \mathrm{m}(2),>20 \mu \mathrm{m}(3)$, bulk (4).

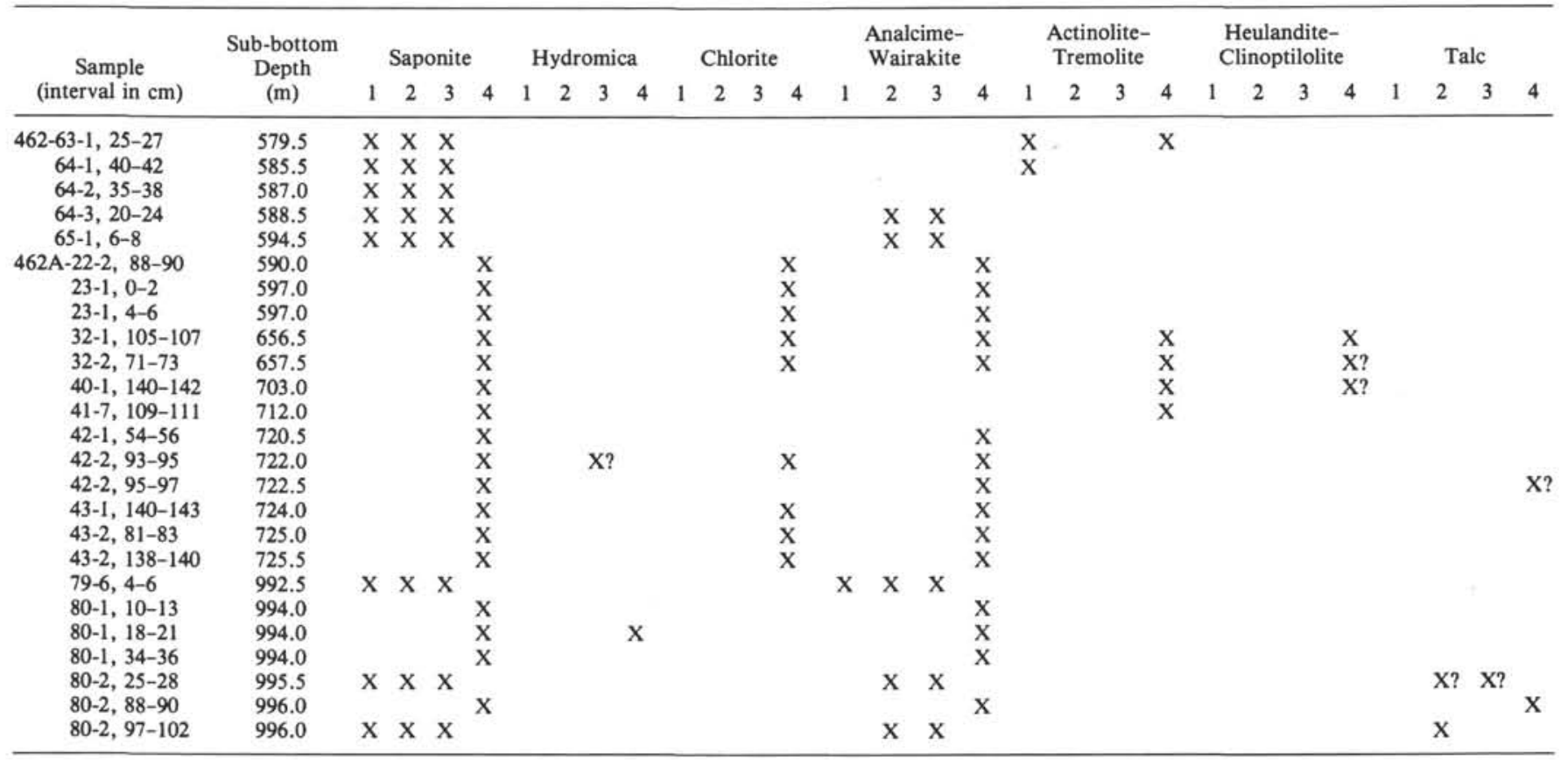




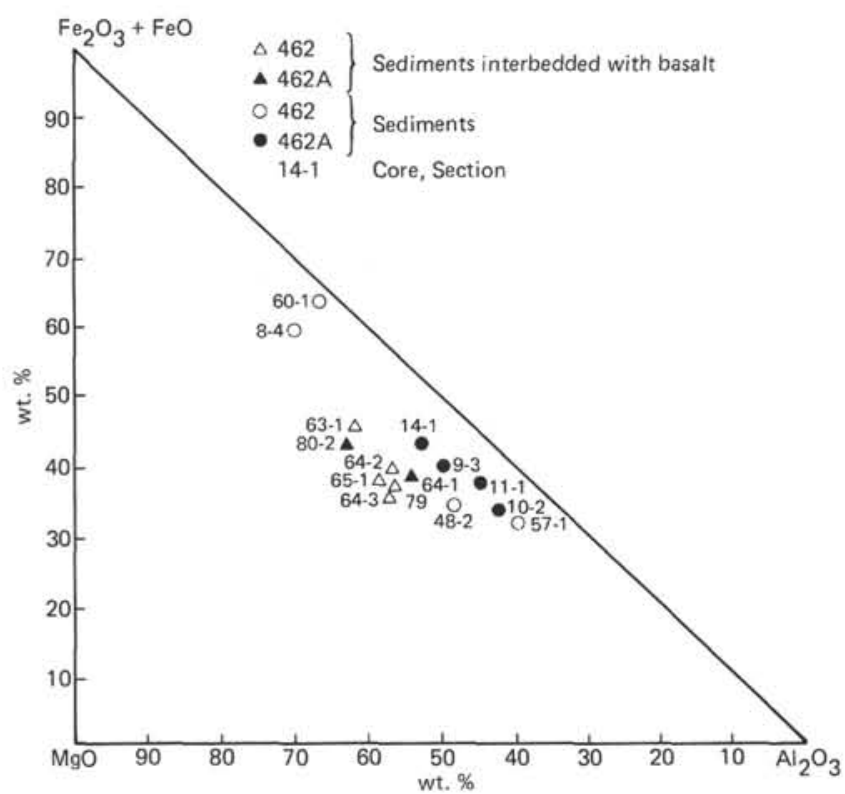

Figure 1. Triangular diagram of $\mathrm{Fe}_{2} \mathrm{O}_{3}+\mathrm{FeO}-\mathrm{Al}_{2} \mathrm{O}_{3}-\mathrm{MgO}$ for clay minerals from sediments and sediments interbedded with basalts at Site 462.

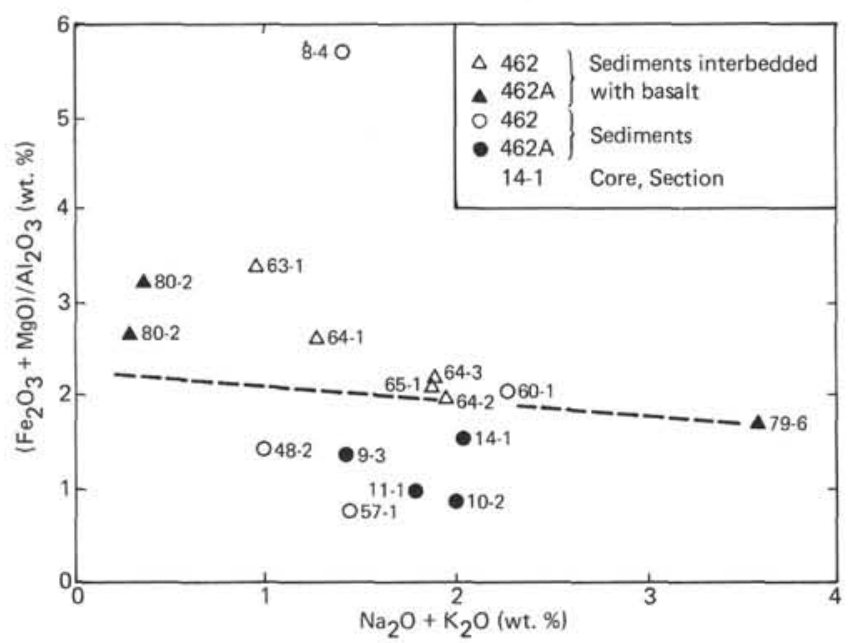

Figure 2. Variation of $\left(\mathrm{Fe}_{2} \mathrm{O}_{3}+\mathrm{FeO}+\mathrm{MgO}\right) / \mathrm{Al}_{2} \mathrm{O}_{3}$ with $\mathrm{Na}_{2} \mathrm{O}+$ $\mathrm{K}_{2} \mathrm{O}$ in clay minerals from sediments and sediments interbedded with basalt at Site 462 .

idizes to $\mathrm{Fe}^{+3}$, and $\mathrm{Mg}$ is released, which may be involved in palygorskite growth.

Growth of quartz and cristobalite-tridymite in the lower part of the sediments of Unit III, at the contact with basalt, irrespective of the type of rock, is connected with the final stages of sill volcanism in Nauru Basin. Sill volcanism also probably influenced the enrichment of the lower part of Unit III in manganese, iron, and potassium. Enrichment of rocks with $\mathrm{SiO}_{2}$ and $\mathrm{K}$ is typical of the zone of solution degassing (Naboko, 1969).

An increase of $\mathrm{Cr}, \mathrm{Ni}, \mathrm{Co}, \mathrm{Sc}, \mathrm{Pb}$, and $\mathrm{Cu}$ in sediments near the contact with basalt is observed in Hole $462 \mathrm{~A}$ (Table 6 ) and is probably connected with the in- fluence of sill volcanism on the material composition of sediments. Growth of metal-bearing sediments at the contact with basalt is widely described in the literature. The genesis of these sediments is questionable, although the majority of authors consider it to be exhalationsedimentary, connected with the leaching of basalts heated (in fractures) by sea water, mainly in rift zones (Lisitsyn, 1978; and others). In Nauru Basin, metalbearing sediments are related to intraplate magmatism.

\section{Unit IV}

Sediments of Unit IV, interbedded with basalts, consist of secondary minerals, mainly $\mathrm{Fe}-\mathrm{Mg}$-saponite. Primary sediments were composed of volcanic glass, probably tholeiitic.

Primary-glass alteration took place at 300 to $500^{\circ} \mathrm{C}$ and resulted in the formation of talc, actinolite-tremolite, analcime-wairakite, and chlorite. The temperature of formation of these minerals, accompanied by sea water-glassy-tholeiitic-basalt interaction, has been determined experimentally (Mottl et al., 1978; Kotov et al., 1978), and is described in this volume (Kurnosov et al.). Heulandite-clinoptilolite probably grew at 100 to $150^{\circ} \mathrm{C}$ (Senderov and Khitarov, 1970). Saponite was formed at lower temperatures. Secondary minerals were formed under reducing, alkalic conditions, similar to those of secondary minerals within basalts of Nauru Basin (Kurnosov et al., this volume).

Besides temperature, the alteration of glass in sediments was influenced by solutions introduced to volcanic sediments from cooling sills. The nature of solutions in sills is considered in this volume (Kurnosov et al.). Sub-vertical veinlets of zeolites discovered by the participants of Leg 61 in sediments of Unit IV testify to this. Saponites from sediments are probably not only the product of in situ glass decomposition; they may also grow from solutions introduced along open fractures in sills. Saponites from volcaniclastic sediments of Unit IV and from veins within basalts are similar in chemical composition and content of minor elements (Tables 3, and 7; Kurnosov et al., this volume).

\section{CONCLUSIONS}

Mineralogical analysis of sediments from Nauru Basin allows us to consider that a complex of calcareous and siliceous sediments, consisting of terrigenous minerals which did not undergo notable diagenetic changes, was formed in Eocene-Pleistocene time. The terrigenous mineral complex reflects common paleogeographic conditions of sedimentation - a regime of oceanic pelagic sedimentation, reef knolls surrounding Nauru Basin, some island alkali volcanism, and suspension flows, introduction of homogeneous clay material to Nauru Basin, and long relative stability of oceanic currents transporting clay minerals to the basin.

In Cretaceous time, volcaniclastic sediments which accumulated in Nauru Basin differ in mineralogical composition both from terrigenous Eocene-Pleistocene sediments and among themselves. Their accumulation suggests active volcanism-probably under-water tholeiitic volcanism in middle Cretaceous time, and sub- 
aerial alkali volcanism on islands surrounding Nauru Basin in Cenomanian-Maestrichtian time. Alteration of volcaniclastic sediments overlying the sill complex and interbedded with it took place under different conditions and ended in the formation of unlike mineralogical associations.

Alteration of middle Cretaceous volcaniclastic sediments within the sill complex took place under conditions close to those of vein mineral formation within basalts of Nauru Basin: $500^{\circ} \mathrm{C}$ and lower, a semi-closed system with difficult water exchange, and an alkalic, reducing regime. As a result, high-and middle-temperature minerals have grown: talc, actinolite-tremolite, analcime-wairakite, chlorite, heulandite-clinoptilolite, and trioctahedral smectite (Fe-Mg-saponite). This association is akin to the complex of secondary minerals in basalts.

Upper Cretaceous volcaniclastic sediments overlying the sill complex were altered by low-temperature interaction with sea water, in an open system. Thus, dioctahedral smectite (Fe-montmorillonite), often clinoptilolite, and sometimes palygorskite are the main secondary minerals.

Comparison of conditions of formation of smectites from volcaniclastic sediments and from basalts (Kurnosov et al., this volume) shows that a semi-closed system (autoclave) and reducing regime (volcaniclastic sediments between sills, groundmass basalt, and veins in basalts) are necessary for the formation of trioctahedral smectites. Under experimental conditions similar to natural ones, trioctahedral smectite is also the main product of tholeiitic basalt alteration (Mottl et al., 1978; Kotov et al., 1978).

Dioctahedral smectites grow under oxidizing conditions in open systems (volcaniclastic sediments overlying the sill complex, volcaniclastic layers in terrigenous Eocene-Pleistocene sediments, and the upper part of the sill complex with celadonite-glauconite; see Kurnosov et al., this volume). The reason for palygorskite concentration in the red clays is obscure.

The proximity of the sill complex manifested itself in silicification (quartz, cristobalite-tridymite) of about 20 meters of sediments overlying basalt, and in an increase in $\mathrm{Mn}, \mathrm{Fe}, \mathrm{K}, \mathrm{Cr}, \mathrm{Ni}, \mathrm{Co}, \mathrm{Sc}, \mathrm{Pb}$, and $\mathrm{Cu}$ in sediments near the contact with basalt.

\section{ACKNOWLEDGMENTS}

We thank Dr. S. A. Shcheka, Dr. N. O. Murdmaa, Dr. H. Okada, and Dr. N. V. Kotov for comments and criticism. We also thank N. V. Gruda, I. V. Kholodkevich, T. V. Sverkunova, L. I. Kovbas, T. L. Plakhova, and N. G. Engovatova for assistance during various parts of the study.

\section{REFERENCES}

Bonatti, E., and Joensuu, O., 1968. Palygorskite from Atlantic deepsea sediments. Am. Mineral., 53:975-983.

1969. Palygorskite from the deep-sea: a reply. Am. Mineral., 54:568.
Butuzova, G. Yu., Dritz, V. A., Lisitsina, N. A., et al., 1979. Dynamics of clay minerals formation in ore-bearing sediments of the Atlantis-II basin. Lithol. Mineral. Res., 1:30-42.

Couture, R. A., 1977. Composition and origin of palygorskite-rich and montmorillonite-rich zeolite-containing sediments from the Pacific Ocean. Chem. Geol. 19:2.

Dritz, V. A., and Sakharov, B. A., 1976. X-Ray Structural Analysis of Mixed-Layer Minerals: Moscow (Nauka).

Griffin, J., Windom, H., and Goldberg, E., 1968. The distribution of clay minerals in the World Ocean. Deep-Sea Res., 15:433-459.

Gorbunova, Z. N., 1970. Clay and other highly dispersed minerals in Pacific sediments. The Pacific Ocean, (Vol. 1); Moscow (Nauka). 1972. Palygorskites in sediments from cores of deep-water drilling in the Pacific Ocean. Trans. Acad. Sci. U.S.S.R., 207:430432.

Kossovskaya, A. G., and Shutov, V. D., 1975. Minerals-Indicators of Geotectonic Types of the Regional Epigenesis and Its Conjugation with Metamorphism on Continents and in Oceans. Crystallochemistry of Minerals and Geological Problems: Moscow (Nauka), pp. 19-34.

Kotov, N. V., Kurnosov, V. B., and Kholodkevich, I. V., 1978. Modelling of natural processes of volcanic rock transformation in pure and model sea water at higher P-T parameters. Lithol. Mineral. Res., 4:78-89.

Kurnosov, V. B., Tseitlin, N. V., and Narnov, G. A., 1980. Clay minerals: paleogeographic and diagenetic aspects. In Scientific Party, Init. Repts. DSDP, 56, 57, Pt. 2: Washington (U.S. Govt. Printing Office), 979-1004.

Lisitsyn, A. P., 1978. Processes of Oceanic Sedimentation. Lithology and Geochemistry: Moscow (Nauka).

Lomova, O. S., 1975a. Abyssal palygorskite clays in the East Atlantic and their genetic relations with alkaline volcanicity (according to the data of the 2nd and 14th Glomar Challenger voyages). Lithol. Mineral Res., 4:10-27.

1975b. Abyssal palygorskite clays of the East Atlantic (Legs 2, 14, "Glomar Challenger"). Crystallochemistry of Minerals and Geological Problems: Moscow (Nauka), pp. 105-115. , 1979. Palygorskites and sepiolites as indicators of geological environments. Trans. Acad. Sci. U.S.S.R., 336:117-123.

Matti, J. C., Zemmels, I., and Cook, H. E., 1973. X-ray mineralogy of sediment from the western Pacific, Leg 20, DSDP. In Heezen, B. C., MacGregor, I. D., et al., Init. Repts. DSDP, 20: Washington (U.S. Govt. Printing Office), 323-334.

1974. X-ray mineralogy data, northwestern part of the Indian Ocean. In von der Borsch, C. C., Slater, J. G., et al., Init. Repts. DSDP, 22: Washington (U.S. Govt. Printing Office), 693-710.

Mering, J., 1975. Smectites. Soil components. Inorgan. Compon., 2: 97-119.

Mottl, M. J., and Holland, H. D., 1978. Chemical exchange during hydrothermal alteration of basalt by seawater. I. Experimental results for major and minor components of seawater. Geochim. Cosmochim. Acta, 42:1103-1115.

Naboko, S. I., 1969. Conditions of Formation and Peculiarities of Recent Hydrothermal Metasomatic Formation of Kurile-Kamchatka Volcanic Arc. Young Hydrothermally Altered Rocks and Minerals of Kamchatka and Kurile Islands: Moscow (Nauka), pp. 3-8.

Peterson, M. N. A., Edgar, N. T., von der Borch, C. C., et al., 1970. Cruise leg summary and discussion. In Peterson, M. N. A., Edgar, N. T., et al., Init. Repts. DSDP, 2: Washington (U.S. Govt. Printing Office), 9-249.

Senderov, E. E., and Khitarov, N. I., 1970. Zeolites, Their Synthesis and Conditions of Formation in Nature: Moscow (Nauka).

Skornyakova, N. S., Kurnosov, V. B., Svalnov, V. N., et al., 1978. Sepiolites and palygorskites in the Indian Ocean. Lithol. Mineral Res., 6:29-45. 

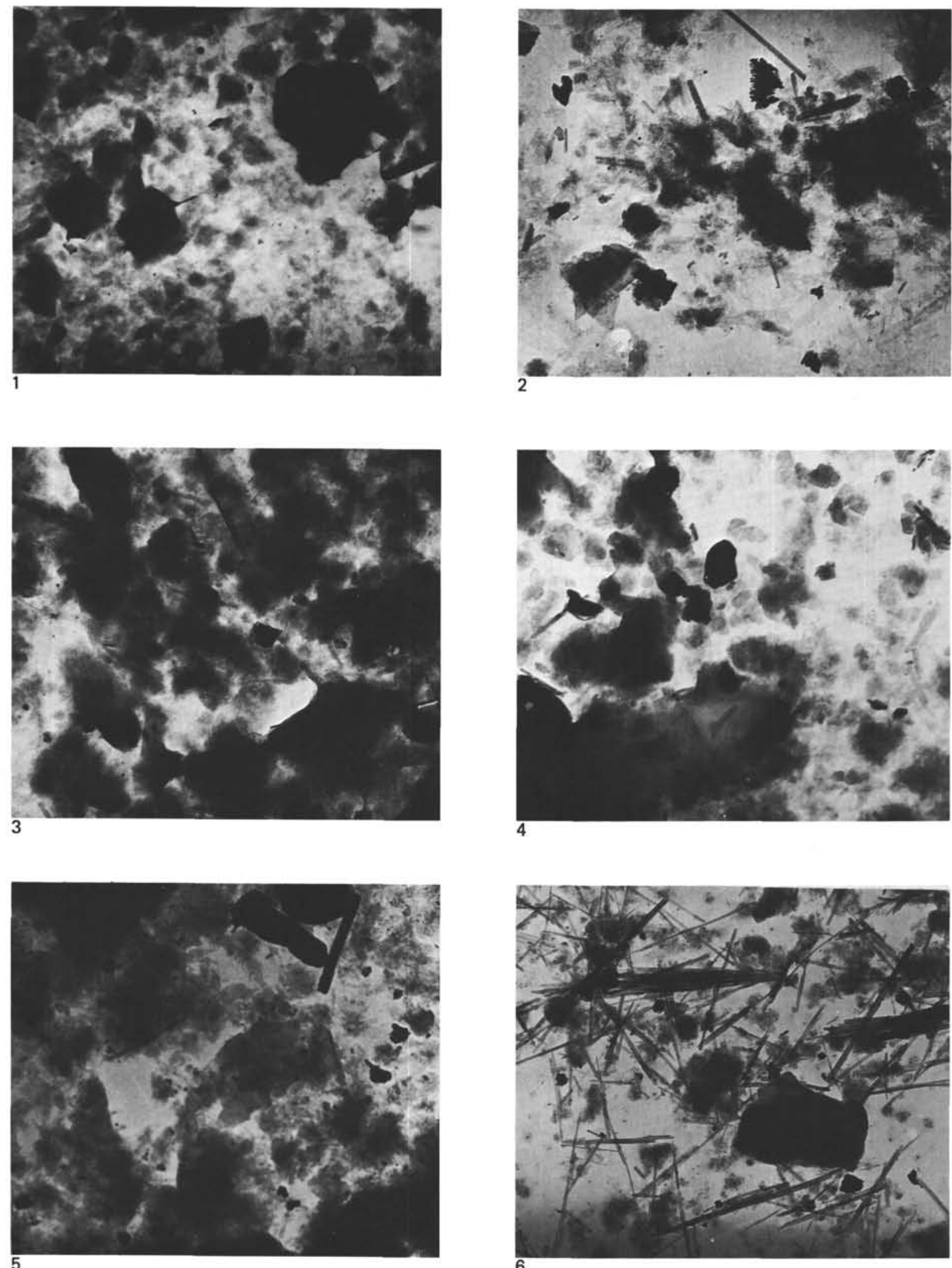

Plate 1. Electron micrographs of clay minerals from sediments and sediments interbedded with basalts, Leg 61 .

Figures 1-3. Fe-montmorillonite. 1. Sample 462-48-2, 75-77 cm, $\times 10,000$ 2. Sample $462 \mathrm{~A}-9-3,58-61 \mathrm{~cm}, \times 20,000$ 3. Sample $462 \mathrm{~A}-11-1,60-64 \mathrm{~cm}, \times 20,000$
Figure 4. Fe-Mg-saponite, $\times 40,000$. Sample $462 \mathrm{~A}-80-1,34-36 \mathrm{~cm}$.

Figure 5. Mixed-layer hydromica-montmorillonite, $\times 40,000$. Sample $462-18-3,74-78 \mathrm{~cm}$.

Figure 6. Palygorskite, $\times 5000$. Sample $462 \mathrm{~A}-10-2,109-116 \mathrm{~cm}$. 

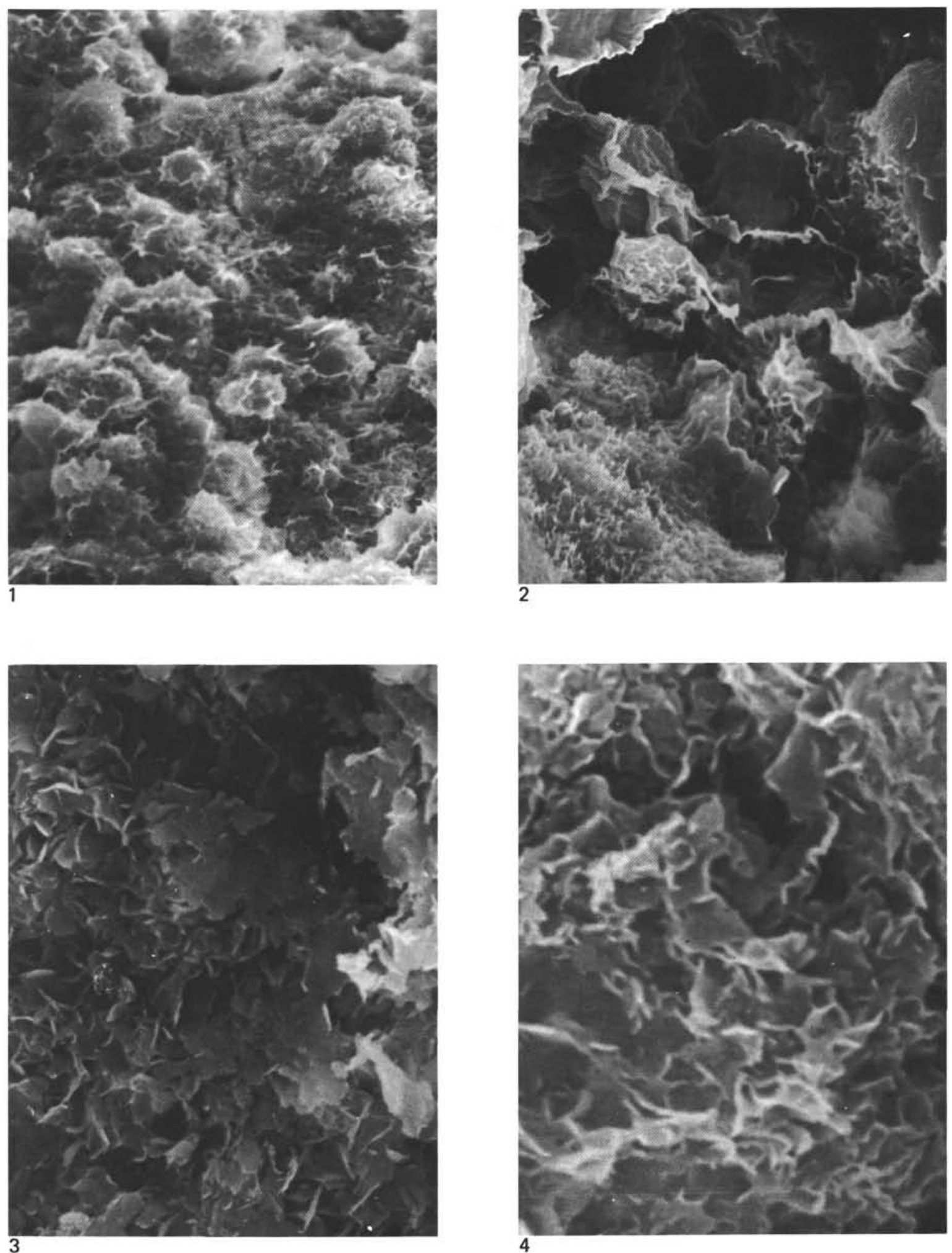

Plate 2. Scanning electron micrographs of smectites from sediments and sediments interbedded with basalts, Leg 61 .

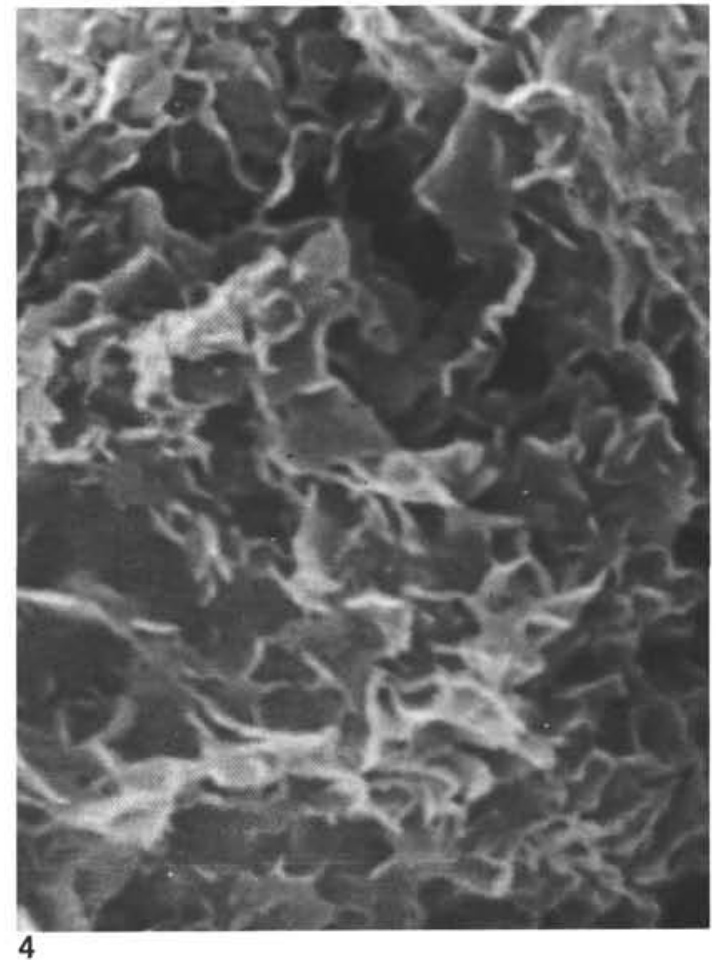

Figures 1, 2. Fe-montmorillinite. 1. Sample 462-48-2, 75-77 cm, $\times 1000.2$. Sample $462-57, \mathrm{CC}, \times 2000$.

Figures 3, 4. Fe-Mg-saponites. 3. Sample 462-65-1, 6-8 cm, $\times 3000$. 4. Sample $462 \mathrm{~A}-80-1,34-36 \mathrm{~cm}, \times 10,000$. 


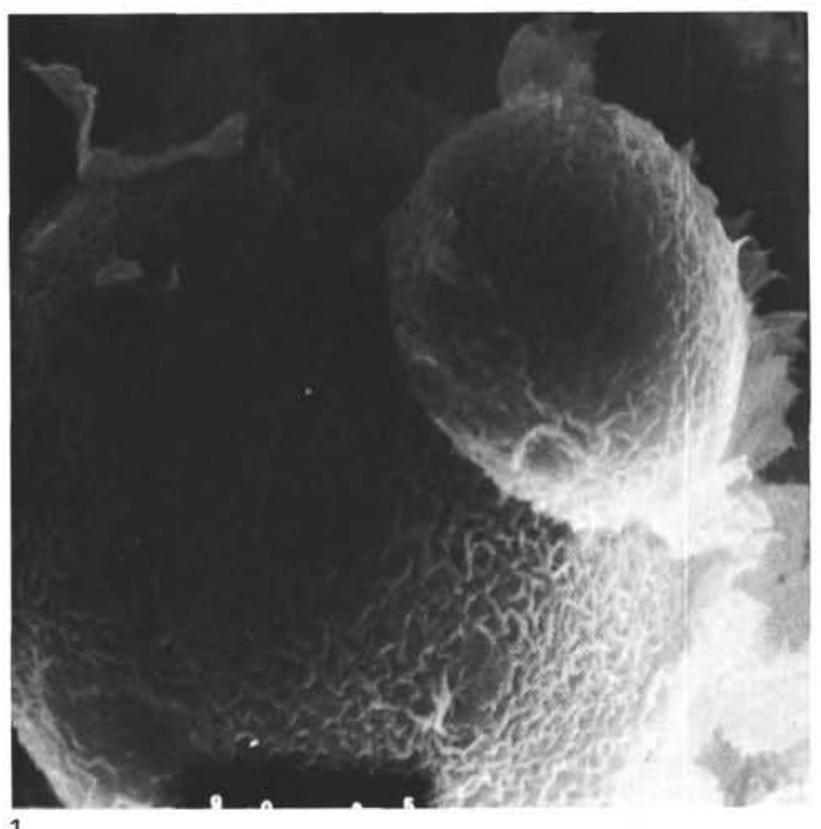

Plate 3. Scanning electron micrographs of secondary minerals from volcaniclastic sediments, Leg 61 .

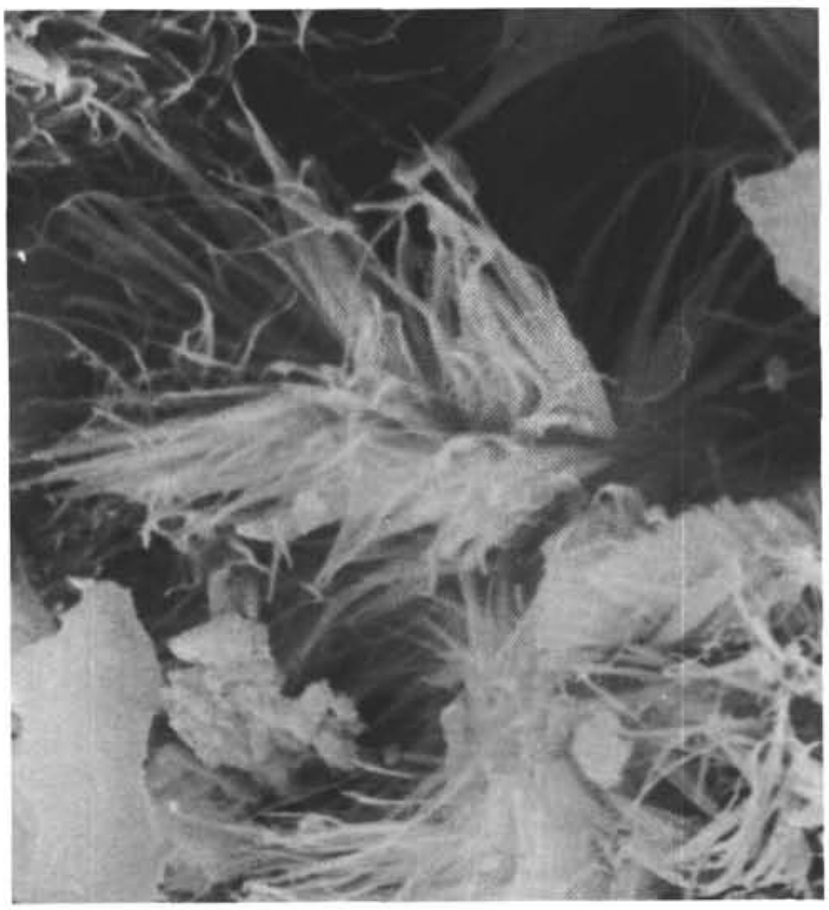

1

Plate 4. Scanning electron micrographs of palygorskite, Leg 61.

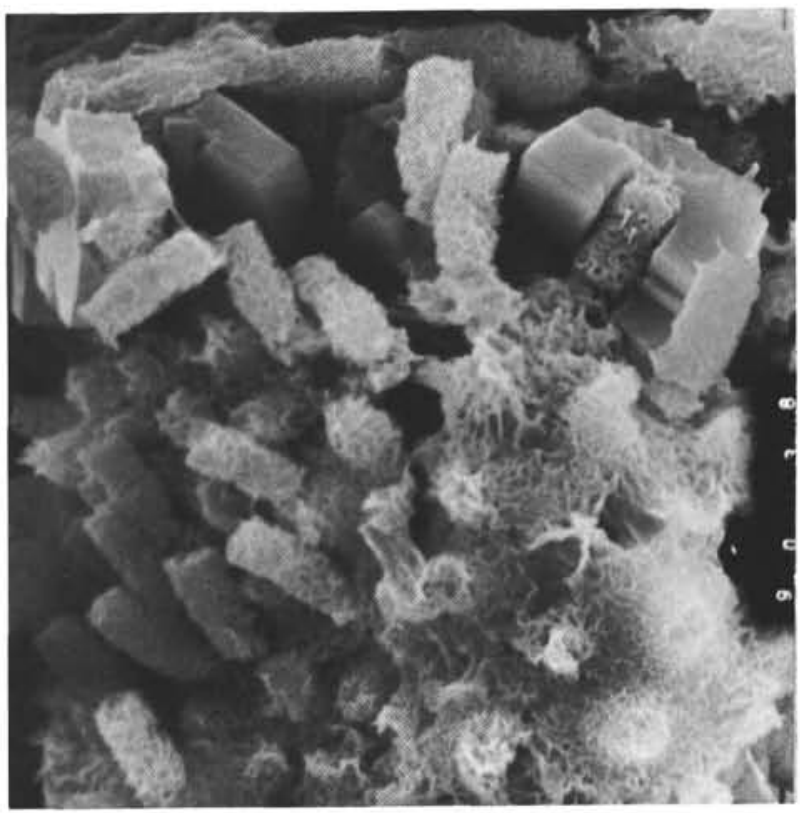

2

Figure 1. Fe-montmorillonite, $\times 2600$. Sample $462-48-2,75-77 \mathrm{~cm}$. Figure 2. Fe-montmorillonite and zeolite, $\times 2000$. Sample $462-57$, CC.

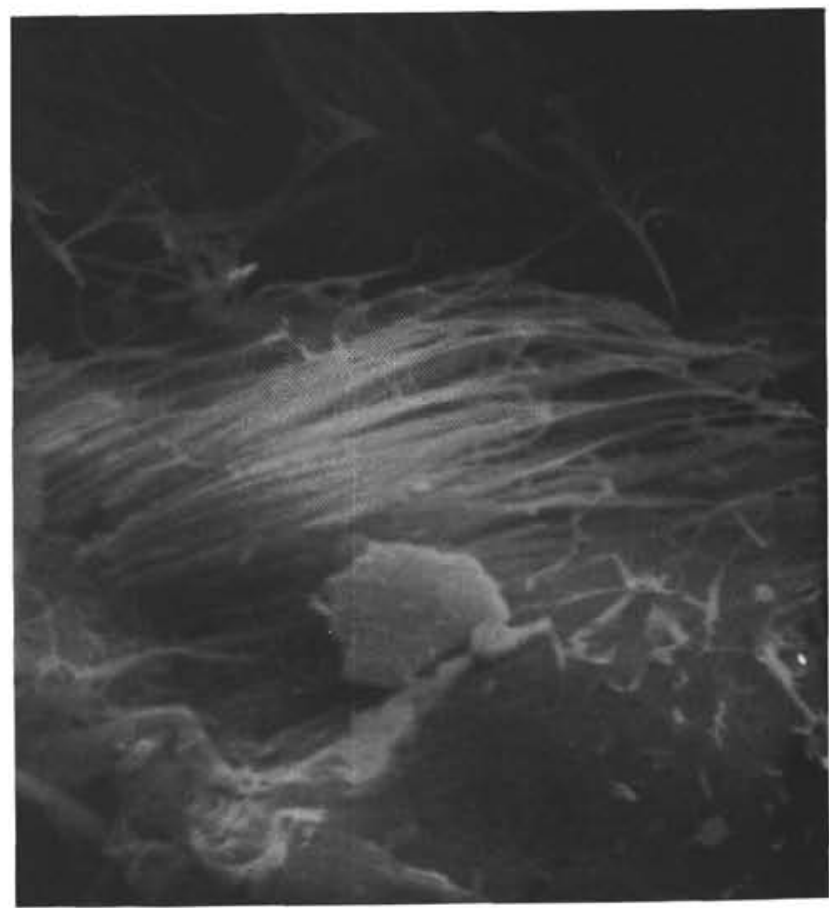

2

Figure 1. Sample 462-50-2, $138-141 \mathrm{~cm}, \times 3000$.

Figure 2. Sample $462-50-2,138-141 \mathrm{~cm}, \times 4000$. 

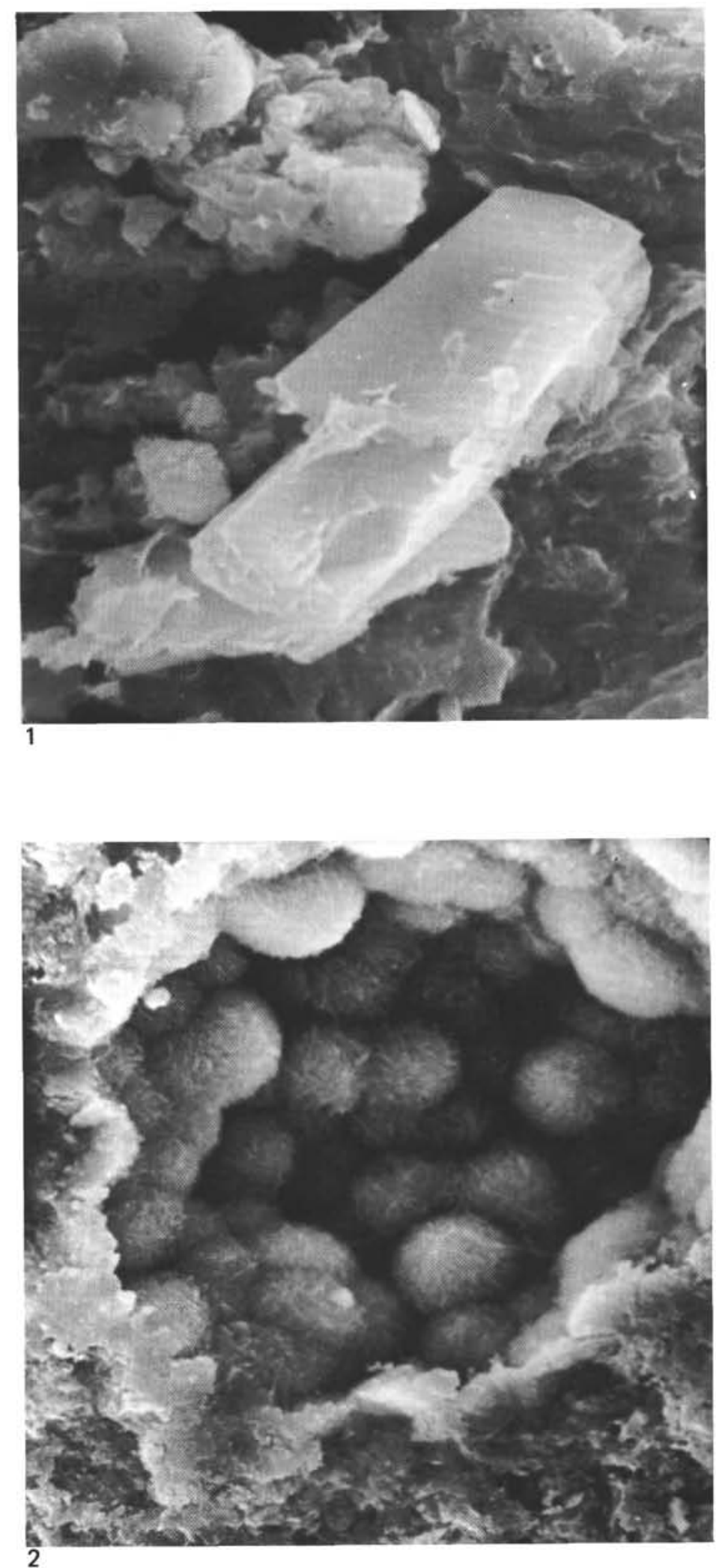

Plate 5. Scanning electron micrographs of secondary minerals, Leg 61.
Figure 1. Clinoptilolite and Fe-montmorillonite, $\times 3000$. Sample 462A-11-1, 60-62 cm.

Figure 2 . Cristobalite-tridymite (opal-CT), $\times 900$. Sample 462-59-1, $0-5 \mathrm{~cm}$. 

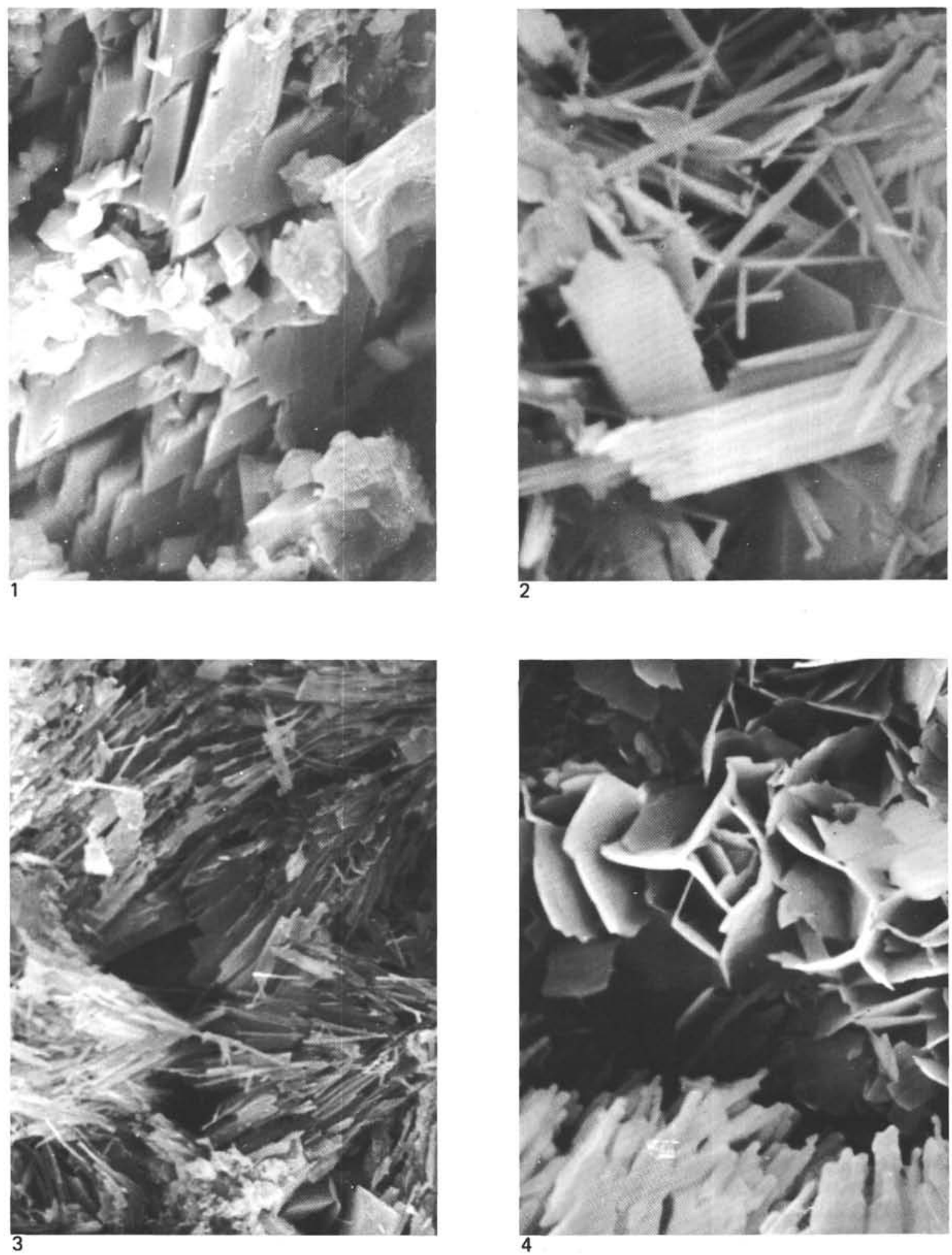

Plate 6. Scanning electron micrographs of secondary minerals, Leg 61.

Figure 1. Analcime-wairakite, $\times 1000$. Sample $462-65-1,6-8 \mathrm{~cm}$.

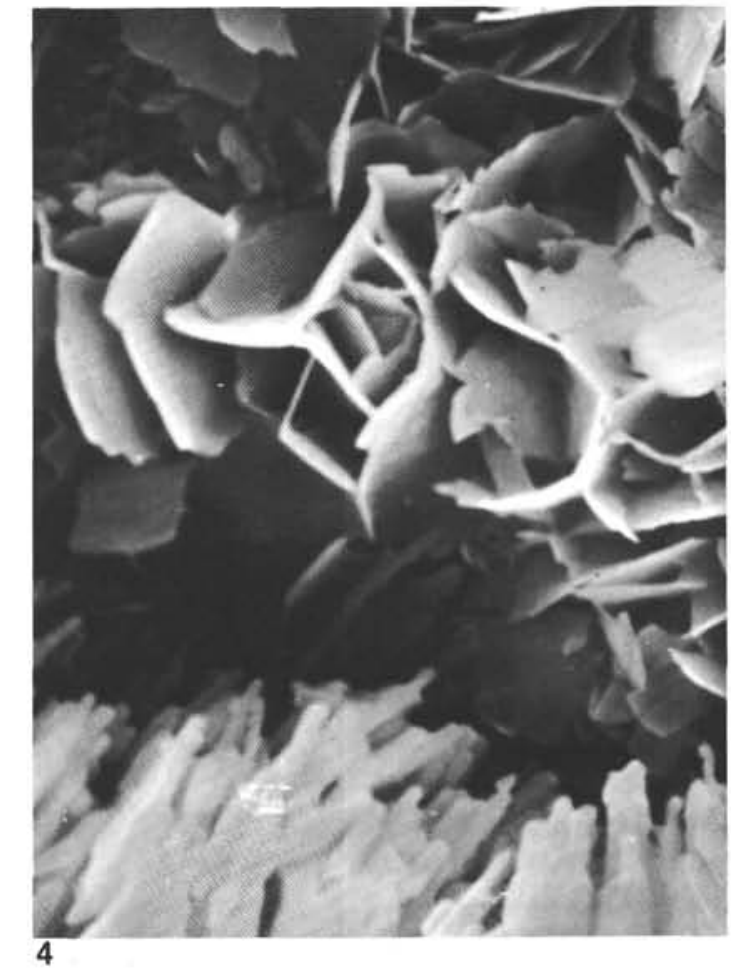

Figure 2. Saponite, $\times 9000$. Sample $462 \mathrm{~A}-32-1,105-107 \mathrm{~cm}$. Figure 3. Zeolite, $\times 4500$. Sample $462 \mathrm{~A}-42-2,95-97 \mathrm{~cm}$.

Figure 4. Smectite (center) and zeolite (below). Sample 462A-43-2, $81-83 \mathrm{~cm}, \times 3000$. 


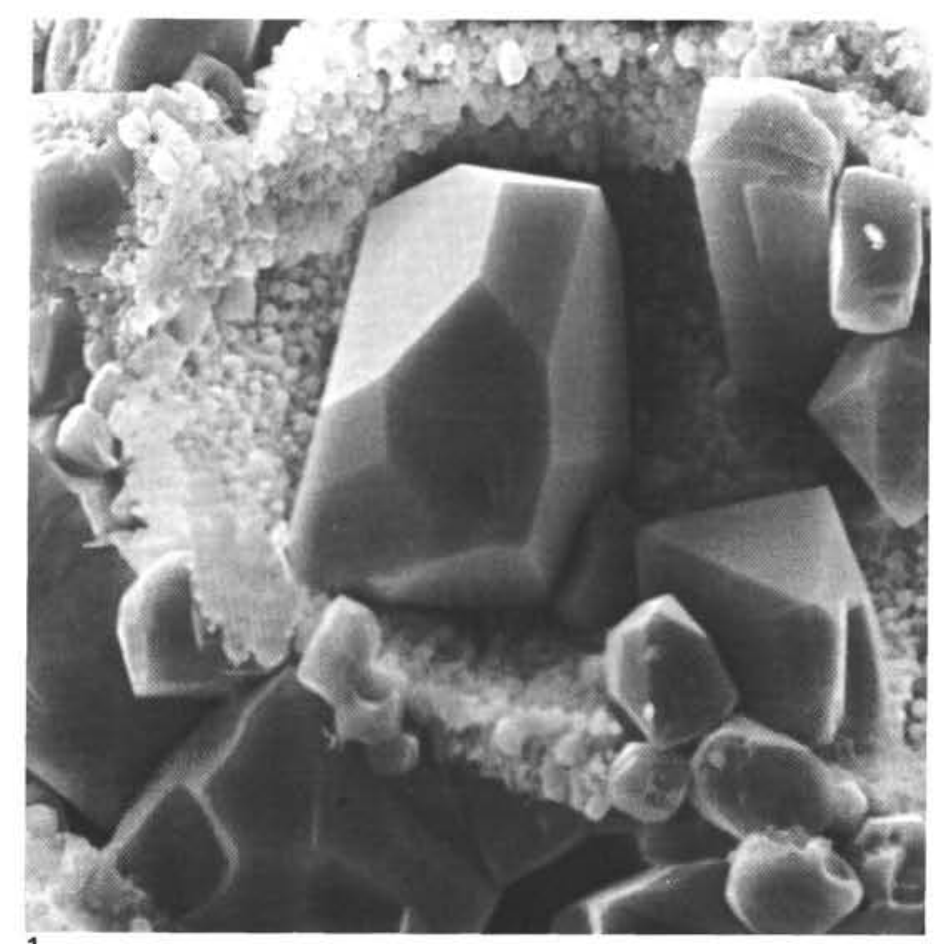

1

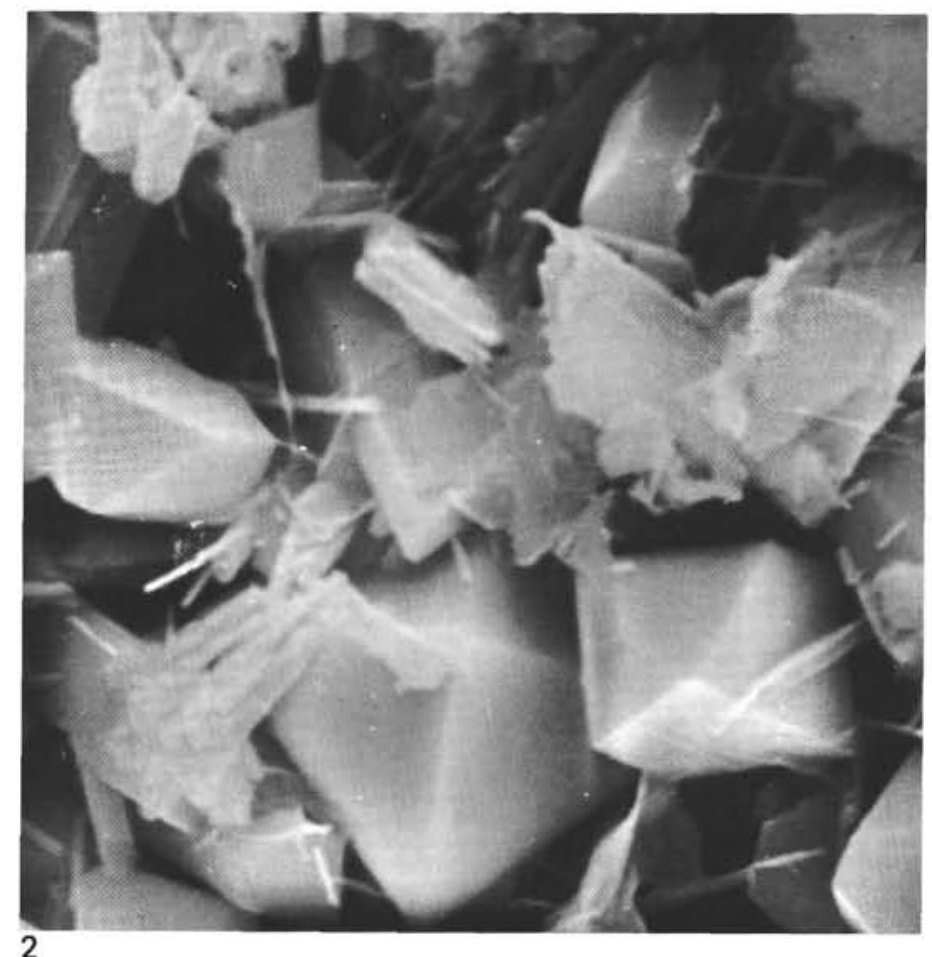

Plate 7. Scanning electron micrographs of secondary minerals, Leg

Figure 1. Clinoptilolite. Sample 462A-7-1, 46-51 cm, $\times 1000$.

Figure 2. Clinoptilolite and needle-like zeolites(?). Sample 462A-42$2,95-97 \mathrm{~cm}, \times 6000$. 